\title{
Assessing Optimal Digital Elevation Model Selection for Active River Area Delineation Across Broad Regions
}

\author{
Shizhou Ma ( $\square$ shizhouma@dal.ca ) \\ Dalhousie University https://orcid.org/0000-0001-8407-6632 \\ Karen Beazley \\ Dalhousie University \\ Patrick Nussey \\ Nature Conservancy Of Canada \\ Chris Greene \\ Dalhousie University
}

\section{Research Article}

Keywords: Riparian Delineation, River Management, Flooding, GIS, Digital Elevation Model

Posted Date: April 23rd, 2021

DOl: https://doi.org/10.21203/rs.3.rs-311838/v1

License: (c) (1) This work is licensed under a Creative Commons Attribution 4.0 International License. Read Full License 


\section{Abstract}

The Active River Area (ARA) is a spatial approach for identifying the extent of functional riparian area. Given known limitations in terms of input elevation data quality and methodology, ARA studies to date have not achieved effective computer-based ARA-component delineation, limiting the efficacy of the ARA framework in terms of informing riparian conservation and management. To achieve framework refinement and determine the optimal input elevation data for future ARA studies, this study tested a novel Digital Elevation Model (DEM) smoothing algorithm and assessed ARA outputs derived from a range of DEMs for accuracy and efficiency. It was found that the tested DEM smoothing algorithm allows the ARA framework to take advantage of high-resolution LiDAR DEM and considerably improves the accuracy of high-resolution LiDAR DEM derived ARA results; smoothed LiDAR DEM in 5-meter spatial resolution best balanced ARA accuracy and data processing efficiency and is ultimately recommended for future ARA delineations across large regions.

\section{Introduction}

Riparian areas are the interface between aquatic and terrestrial systems along inland

watercourses (Naiman and Décamps 1997). They cover a small proportion of the landscape mosaic but play important roles in both terrestrial and aquatic ecosystems. Riparian plant communities support numerous functions including sediment deposition on floodplains and woody debris supply. Movement of water and organic materials within riparian areas makes freshwater ecosystems one of the most biologically diverse and rich systems (National Research Council 2002). Riparian areas are also among the most degraded ecosystems due to human disturbances, through changes in hydrologic regime, removal of vegetation, hardening of shorelines and other impacts (Smith et al. 2008). Given the important ecological role of riparian areas and the degradation caused by human disturbances, effective riparian management is warranted and should include the conservation and restoration of physical and ecological processes of the river and adjacent land area (Smith et al. 2008). The initial stage of riparian management is to define and delineate the functional riparian area extent, which is important for both ecological and managerial reasons (llhart et al. 2000). By understanding the extent of riparian area and how rivers interact with adjacent lands, managers can better recognize the processes involved and how to design zone management, protection and restoration efforts to more effectively conserve riparian areas.

Delineating the functional riparian area extent, however, is not a straightforward task and may require the understanding of local-scale environmental conditions since riparian functional attributes depend on sitespecific variations such as landscape composition and environmental setting (Naiman and Décamps 1997). Given these challenges, riparian management projects have typically applied a "fixed-width buffer guideline" (Kuglerová et al. 2020). Unfortunately, fixed-width buffers may ultimately fail in meeting management goals as they do not account for variations in site-specific attributes (e.g., river slope and bank topography), and likely underestimate the full extent of riparian areas (Kuglerová et al. 2014). 
The Active River Area (ARA) framework (Smith et al. 2008) was developed to address challenges associated with shortcomings in standard buffer-width guidelines. To facilitate delineation of key functional riparian areas, the framework separates the area into five components-floodplain, terrace, meander belt, riparian wetland, and material contribution zone-based on the valley setting and geomorphic stream type (Smith et al. 2008). The most extensive application of the ARA framework to date was collaboratively conducted by The Nature Conservancy (TNC) and the Nature Conservancy of Canada (NCC) for the Northern Appalachian / Acadian Ecoregion, based on 30-m Shuttle Radar Topography Mission (SRTM) DEM and national scale hydrologic network (1:100,000 U.S. National Hydrography Dataset and 1:50,000 Canadian National Hydrographic Network) (TNC 2015; Nussey and Noseworthy 2020). Although laudable for applying ARA delineation across a large geographic area, its limitations are acknowledged in accuracy of component outputs, especially floodplain and terrace separation, associated with the input DEM quality (Nussey and Noseworthy 2020). Failure to differentiate terraces from modern floodplains is due to the vertical imprecision of commonly-used SRTM DEMs (i.e., $10 \mathrm{~m}$ and $30 \mathrm{~m}$ ), and limits the utility of the results for management purposes (Smith et al. 2008). Refinements of methods and input elevation data are therefore required for more precise yet technicallyfeasible ARA application in large geographies.

Theoretically, the spatial extent of ARA components is heavily controlled by stream and valley morphology (Smith et al. 2008). The use of DEMs and digitized hydrological networks should achieve effective ARA delineation by synthesizing river geomorphology into a spatial ARA framework. Previous studies reveal that DEM characteristics (i.e., horizontal resolution and vertical accuracy) play important roles in topographic and hydrologic modelling (Tan et al. 2018; Roostaee and Deng 2020). The accuracy of active river area delineation therefore relies heavily on the properties of the input DEM. Generally, high quality DEMs, such as Light Detection and Ranging (LiDAR) derived DEMs, provide a detailed representation of topography (Zhao et al. 2010), which can benefit river valley morphology modelling. High resolution DEMs, however, have their own limitations and are not necessarily better than lower resolution DEMs in terms of topographic representation and hydrologic modelling (Tan et al. 2018). A very high-resolution LiDAR DEM, for instance, could result in the representation of a terrain surface that is much more detailed than necessary for the process being modelled (Ziadat 2007), potentially creating errors in hydrologic modelling and ARA delineation, and imposing challenges with increased data storage and computational intensity requirements for processing and manipulation (Lin et al., 2010).

Studies focused on selecting optimal DEMs that satisfy both data processing and storage capabilities and representation of spatial variability for ARA modelling are necessary. To date, efforts have been made to identify optimal input DEMs for several flood inundation and riparian area delineation models (e.g., TOPMODEL, SWAT, Bathtub) (Suliman et al. 2016, Goyal et al. 2017, Fereshtehpour and Karamouz 2018). However, no ARA-related studies have carried out accuracy-efficiency analyses to identify optimal input DEM, limiting the efficacy of the ARA framework and confidence in modelled outputs in riparian conservation and management contexts. Moreover, the advantages of high-resolution LiDAR DEMs in terms of topographic and hydrologic modelling have been hindered by excessive surface roughness, resulting from over-detailed topographic representation (Lindsay et al. 2019). To allow the ARA 
framework to take advantage of high-resolution LiDAR DEMs, an appropriate DEM smoothing algorithm must be applied to subdue surface roughness before commencing ARA delineation. Therefore, the primary objectives of this study were to achieve methodology improvement and identify optimal input DEM for future ARA delineation across large regions. To achieve these objectives, this study (i) tested whether the application of high-resolution LiDAR DEM can achieve floodplain and terrace separation based on developed separation framework; (ii) delineated the ARA components using the refined ARA framework and various resampled LiDAR DEMs and 30-m SRTM DEM; (iii) assessed the performance of DEMs on ARA delineation by comparing the spatial extent of different DEMs-derived ARAs; (iv) identified and tested an appropriate DEM smoothing algorithm to reduce the surface roughness of high-resolution LiDAR DEM; (v) conducted error analyses for DEMs of varying resolutions and sources and analyzed DEM-induced topographic and hydrologic modelling uncertainties; and, (vi) applied an accuracy-efficiency tradeoff analysis to select the optimal DEM for future ARA studies, especially in large regions.

\section{Materials And Methods}

\subsection{Study Watersheds}

To delimit the scope while maintaining a hydrologically meaningful boundary, two watersheds-Lower St. John River Watershed and Miramichi River Basin (Fig. 1) -were selected from the Canadian Hydrological Unit (CHU) system (Noseworthy et al. 2019) at the CHU-6 watershed level (Supplementary Information [SI] 1). The watersheds are located within the province of New Brunswick, Canada, where full 1-m LiDAR DEM coverage is available. The Lower St. John River Watershed and Miramichi River Basin represent topographical variation within the study region, with elevational ranges above mean sea level of $-5-553$ m and $-4-763$ m, respectively; and comprise areas of similar sizes (i.e., 14,343 km² and 12,069 km², respectively). The main stems are the Lower St. John River, which is fed by many significant tributaries (i.e., Nashwaak, Oromocto, and Kennebecasis Rivers) and flows into the Bay of Fundy, and the Miramichi River, which comprises two main branches (i.e., Southwest Miramichi River and Northwest Miramichi River), and drains into Miramichi Bay in the Gulf of St. Lawrence.

\subsection{Data Acquisition and Preparation}

Input datasets included 1-m LiDAR DEM, 30-m SRTM DEM, New Brunswick Hydrographic Network (NBHN), provincial forest soils data, and satellite derived flood extent (Table 1). The elevation datasets (i.e., LiDAR-DEM and SRTM-DEM) and NBHN were key input datasets for the ARA delineation, while other ancillary datasets served to set parameters and calibrate results.

To produce multi-resolution LiDAR DEM for test purposes, the 1-m LiDAR DEM was resampled into five lower resolution DEMs (i.e., 3-m, 5-m, 10-m, 15-m, 30-m) using Bilinear interpolation, which determines the new value of a cell based on weighted-distance average of the four nearest input cell centers. The NBHN is a digital hydrological network, with a general horizontal accuracy of $\pm 2.5 \mathrm{~m}$ (DataQC 2009).

Table 1 Brief descriptions of applied datasets 


\begin{tabular}{|llll|}
\hline Dataset & Brief description & $\begin{array}{l}\text { Original } \\
\text { format }\end{array}$ & Source \\
\hline $\begin{array}{l}\text { LiDAR- } \\
\text { derived } \\
\text { DEM }\end{array}$ & $\begin{array}{l}\text { LiDAR-derived DEMs in } \\
\text { 1-m resolution in New } \\
\text { Brunswick Stereographic } \\
\text { Double Projection. }\end{array}$ & $\begin{array}{l}\text { GeoTiff } \\
\text { (.tif) }\end{array}$ & $\begin{array}{l}\text { http://geonb.snb.ca/nbdem/ } \\
\text { (Date: 2019-05-31) }\end{array}$ \\
\begin{tabular}{|llll} 
SRTM- \\
DEM
\end{tabular} & $\begin{array}{l}\text { SRTM-DEM in 30-m } \\
\text { resolution in WGS 84 } \\
\text { Horizontal Datum }\end{array}$ & $\begin{array}{l}\text { GeoTiff } \\
\text { (.tif) }\end{array}$ & https://earthexplorer.usgs.gov/ \\
& $\begin{array}{l}\text { Surface drainage } \\
\text { features including rivers, } \\
\text { streams, lakes, and }\end{array}$ & $\begin{array}{l}\text { Shapefile } \\
\text { (.shp) }\end{array}$ & http://www.snb.ca/geonb1/e/DC/NBHN.asp \\
& $\begin{array}{l}\text { islands. } \\
\text { (Date:2018-08-29) }\end{array}$ \\
\hline $\begin{array}{l}\text { Forest } \\
\text { soils }\end{array}$ & $\begin{array}{l}\text { Polygons of forest Soils } \\
\text { units, including } \\
\text { information on drainage, } \\
\text { slope, and aspect. }\end{array}$ & $\begin{array}{l}\text { Shapefile } \\
\text { (.shp) }\end{array}$ & http://www.snb.ca/geonb1/e/DC/forestsoils.asp \\
(Date:2015-08-18) \\
\hline $\begin{array}{l}\text { Existing } \\
\text { flood } \\
\text { extent }\end{array}$ & $\begin{array}{l}\text { Landsat imagery } \\
\text { derived-flood extent in } \\
\text { the year of 2011 }\end{array}$ & $\begin{array}{l}\text { Shapefile } \\
\text { (.shp) }\end{array}$ & http://www.snb.ca/geonb1/e/DC/floodraahf.asp \\
\hline
\end{tabular}

\subsection{Stream Classification}

The Strahler stream order system (Strahler 1957) was applied to separate NBHN watercourses into five size classes (i.e., Great, Medium, Small Rivers, Creeks and Headwaters) based on their Strahler order numbers (SI 2). In ARA delineation, extents of riparian basezones (i.e., floodplains and terraces) are determined by measuring relative costs of water traveling upslope from rivers, with higher costs for greater elevations and distances (Barnett 2011). Cost surfaces are continuous and therefore cost thresholds are required to cut-off areas unlikely to be dynamically linked to the streams. Larger rivers have more water volume than smaller rivers, so their floods cover higher costs. Accordingly, cost thresholds need to be determined for rivers in different size classes separately.

\subsection{Active River Area Delineation}

To improve the efficacy of the ARA framework, methodological refinements were made for separating floodplains and terraces and delineating material contribution zones. Given that environmental conditions vary along meandering watercourses and are difficult to predict without the support of an interdisciplinary research team, this study did not quantify the extent of meander belts. To test the performance of different DEMs on the remaining four components of ARA delineation, the refined framework was first applied using various input DEMs. The spatial extents resulting ARA outputs were then compared to illustrate differences generated by variations in DEM resolution and source.

\subsubsection{Floodplain and Terrace Delineation}


To delineate the extent of riparian basezones (i.e., floodplains and terraces), watercourse grids were treated as source cells from which the least accumulated cost distance for every output cell location was calculated. Friction surfaces were generated from slope grids (in degrees) of the different DEMs. With source cells and friction surfaces determined, the "Cost Distance" algorithm in ArcGIS Pro" (ESRI 2018) was performed on each slope grid, moving outward from the input watercourse grid (Fig. 2).

Satellite-derived flood extent was then applied to calibrate cost thresholds for each river size class. For creeks and headwaters where the satellite-derived flood extent was not consistently mapped, cost thresholds tested by NCC (Nussey and Noseworthy 2020) were applied (SI 3). Finally, to avoid problems with the cost-threshold-derived riparian basezone extending an unrealistic distance from the river in flat areas and skipping across bays and estuaries along the coast, riparian basezones were clipped at Euclidean distances from rivers, based on river size (Nussey and Noseworthy 2020): great rivers at 3219 m; medium rivers, 2414 m; small rivers, 1609 m; and headwaters/creeks, 1609 m.

Once riparian basezone extents were determined, efforts were made to separate terraces from floodplains. A novel separation framework which takes advantage of high-resolution LiDAR DEMs (i.e., 3 $\mathrm{m}$ and $5 \mathrm{~m}$ ) was developed and tested. The proposed separation framework aims to detect the cost distance value underneath the transition lines between floodplain and terrace in slope and planform to differentiate the terrace from floodplain. The locations of transition lines were determined by analyzing river valley profiles extracted from high-resolution LiDAR DEMs. River valleys were classified into three categories based on their profiles: V-shape, U-shape and UT-shape (U-shape with terraces) (Fig. 3). A Vshape valley is relatively narrow, suggesting active incision. A U-shape valley is flat-bottomed, indicating that the valley wall is widening or the bottom is undergoing aggradation. A UT-shape valley is flatbottomed with terraces, indicating that geomorphic signatures of former high river levels have been preserved (Yan et al. 2017); fluvial terraces exist only within UT-shaped river valleys. Based on the location of the first level terrace on the valley profile map (Fig. 3c), the floodplain-terrace transition line can be identified over the cost distance surface, and thereafter the underlying cost distance value of the transition line can be extracted. To get a representative cost threshold for terraces and floodplains separation, several cross-sectional lines were created for different rivers in the same size class; the average of the extracted cost distance values was then calculated and used as the separation threshold for that river size class.

\subsubsection{Riparian Wetland Delineation}

Riparian wetlands are low-gradient areas with inundated or hydric soils from high surface water and/or groundwater levels. To detect land areas with relevant features, topography and flow accumulation patterns were modelled separately. Topography patterns were modeled by analyzing slope change across the watersheds; flow accumulation patterns were modelled by creating flow accumulation grids (SI 4). 'Topography Moisture Index' (TMI) (Barnett 2011) was then calculated based on the following formula.

\section{See formula 1 in the supplementary files.}


A high TMI value indicates a high flow accumulation value and a low slope value, and therefore areas with high TMI values may be considered potential wetlands. The extent of riparian wetland was then determined by applying a wet-dry threshold calibrated by provincial wetland and hydric soil data.

\subsubsection{Material Contribution Zone (MCZ) delineation}

Based on a review of buffer sizes for riparian conservation regulation (Environmental Law Institute 2003), MCZ width was determined as $60 \mathrm{~m}$. This was found to be inadequate for delineating MCZs for rivers located in confined valleys with steep slopes that extend beyond $60 \mathrm{~m}$ (Fig. 4). If slopes adjacent to streams have a $15 \%$ or greater rise, sediments and nutrients will enter from areas beyond $60 \mathrm{~m}$ to the top of the slope (Nussey and Noseworthy 2020). To address this, a component named 'ARA steep slope area' (i.e., from stream to top of $\geq 15 \%$ slope) was introduced and delineated to supplement the 60 -m-buffer MCZ (SI 5).

\subsubsection{ARA components combination}

The ARA components were combined in descending order based on their flooding likelihood to delineate the final ARA extents (SI 6), where (i) is considered of greatest likelihood of flooding: (i) ARA Floodplain combination (wet), (non-wet); (ii) ARA Terraces combination (wet), (non-wet); (iii) ARA riparian wetland; (iv) Headwater system (headwater basezone and headwater wetland); (v) Steep slope area; and, (vi) 60-m riparian buffer.

\subsection{High-Spatial Resolution LiDAR DEM Smoothing}

Surface roughness in high-resolution DEM surfaces has been found to inevitably affect the characterization of macro-scale topography (Lindsay et al. 2019), ultimately affecting the accuracy of ARA results. DEM smoothing algorithms, commonly low-pass filters (i.e., mean, median and Gaussian filters), are frequently applied to LiDAR DEMs to lessen the surface roughness before commencing topographic and hydrologic modelling (Gallant 2011). These techniques, however, have a tendency to blur edges of important topographic and drainage features (e.g., ditches, gullies, etc.) (Lindsay et al. 2019). The ability of high-resolution LiDAR DEMs to represent these local-scale features provides the justification for their application in many studies (Zhao et al. 2010; Tan et al. 2018). Thus, it is counter-productive to smooth high-resolution DEM if the outcome is the removal of important topographic information.

The DEM smoothing algorithm applied in this study is the "Feature-Preserving DEM Smoothing" algorithm (FPDEMS) (Lindsay et al. 2019), specifically designed to smooth DEMs while preserving important topographic features. The smoothing processes was automatically carried out by the 'FeaturePreservingSmoothing' tool, available in the open-source geospatial analysis platform, Whitebox GAT (Lindsay 2019). Three mail tool parameters were used $-11 * 11$ kernel, $15^{\circ}$ threshold, and 3 iterations for 5-m LiDAR DEM data; and more aggressively, 17*17 kernel, $25^{\circ}$ threshold, and 5 iterations for 3-m LiDAR DEM data-representing a compromise between processing time and performance (Lindsay et al. 2019). 


\subsection{DEM Error and Uncertainty Assessment}

Three types of DEM errors were considered, arising from resampling, data sources and smoothing. Errors were estimated by computing Root Mean Square Error (RMSE) for each DEM with respect to the reference elevation dataset (Equation 2),

\section{see formula 2 in the supplementary files.}

where ' $\mathrm{Zt}$ ' refers to the elevation value for the 'ith' point obtained from the reference dataset, ' $Z \mathrm{p}$ ' is the elevation value for the 'ith' point obtained from the lower quality DEMs, and ' $n$ ' is the total number of points for which elevation values were retrieved.

The reference dataset comprised elevations obtained from the 1-m LiDAR DEM. To calculate the RMSE, points (i.e., 1000) were randomly generated and evenly distributed across landscape types as ground control points (GCPs) in each watershed (Fig. 5). Slopes and TMIs derived from different DEMs were selected and applied to analyze the effect of DEM qualities on topographic and hydrologic modelling, as these are major indices for riparian basezone and riparian wetland delineation, respectively.

\subsection{Computer-Based Accuracy-Efficiency Tradeoff Analysis}

Tradeoff analyses were conducted by separately measuring accuracy and efficiency components of different parallel ARA analyses. The measurement of ARA output accuracy involved the derivation of Kappa Coefficients based on comparison of delineated and reference ARA components for a set of specific locations (Foody 2002). Given the absence of field verification data and high-resolution aerial imagery, and the potential error of 3-m LiDAR DEM derived ARA caused by over-detailed topographic representation, the reference dataset used was the 3-m smoothed DEM-derived ARA. The GCPs (Fig. 5) were then applied to extract the underlying ARA components from the reference DEM and other DEMderived ARAs for confusion matrix creation.

For efficiency, computational effort expressed as time spent to run key geoprocessing tools was assessed. Among various geoprocessing tools applied for ARA delineation, "Cost Distance" and "Flow Accumulation" are the most time-consuming tools. Runtimes for these two geoprocessing tools considerably increase with higher DEM resolutions. Thus, runtimes of these two tools were considered as efficiency components and applied for comparison against accuracy assessment results.

\section{Results And Discussion}

\subsection{Variations in Spatial Extent of Different DEM-derived ARAs}

Riparian basezone is the dominant component of the active river area in all spatial resolutions and sources of DEM-derived ARA results. The proportion of riparian basezone located on the "wet" area is greater than that on the "non-wet" area in all DEM-derived ARA results (Table 2). This is to be expected, since riparian basezones are generally low-gradient areas with hydric soils, having the same features as 
riparian wetlands. However, riparian basezones derived from different LiDAR-DEMs vary in their spatial extent (Table 2), especially in creek and headwater areas (Fig. 11 and Fig. 12). A negative relationship between the LiDAR-DEM spatial resolution and the total area of the riparian basezone can be detected in both study watersheds. For instance, the total basezone areas (wet and non-wet) in the Miramichi River Basin range from $1711.66 \mathrm{~km}^{2}$ (30-m resolution) to $3238.17 \mathrm{~km}^{2}$ (3-m resolution) (Table $2 \mathrm{~b}$ ). Additionally, while similar boundary extents were detected for riparian basezones of great, medium and small rivers (Fig. 6), more blank areas (i.e., no riparian basezone delineated) were found within the extents of highresolution LiDAR DEM derived riparian basezones (Fig. 11). By visually inspecting the aerial photo of those blank areas, it was evident that most of the blank areas are human infrastructural features with sharp boundaries. Because high-resolution LiDAR DEMs can generate more detailed slope grids and have the ability to model subtle topographic transitions, human infrastructure with sharp boundaries can be represented and will receive high-cost distance values, which will ultimately exclude them from the extent of riparian basezone, resulting in a more precise riparian basezone extent. Accordingly, it is reasonable to suspect that low-resolution LiDAR DEMs will overpredict the riparian basezone extent at certain areas (e.g., human encroachment areas).

LiDAR DEMs in 3-m and 5-m spatial resolution were found to provide sufficiently detailed elevational and horizontal distance changes in river valleys to allow differentiation of terraces from floodplains for great, medium and small rivers. The floodplain and terrace separation results show that the floodplain is the dominant component within the riparian basezone for rivers in those size classes (Fig. 7). Similar to floodplain distribution, larger proportions of terraces are located on "wet" areas than "non-wet" areas in both study watersheds (Table 2). However, due to the appearance of excessive local surface roughness (Fig. 8), accurate valley morphology information for small streams (i.e., creeks and headwaters) was not able to be extracted, as causes (i.e., presence of terraces or surface roughness) of abrupt slope changes were indistinguishable.

By visually comparing the riparian wetland extents derived from different LiDAR-DEMs, it was found that the extents of high-resolution riparian wetland match better than those of low-resolution with the provincial wetland inventory (Fig. 9). Low-resolution LiDAR DEMs and SRTM DEM based analyses were found to underpredict the extent of riparian wetland and overlapping areas of riparian basezone and riparian wetland (Table 2). Such overlapping areas are considered important in conservation planning because highly productive and diverse riparian plant communities tend to establish themselves in areas with rich alluvial soils (Smith et al., 2008). The underprediction issue in low quality DEM-based analyses can therefore be problematic in riparian conservation planning.

Steep slope areas are concentrated in relatively small portions of both study watersheds (Fig. 10). The area of steep slope MCZs increases as the resolution of LiDAR DEM becomes higher, with the same trend in both watersheds (Table 2). For example, the area of steep slope MCZs increases from $671.7 \mathrm{~km}^{2}$ (30-m LiDAR) to $1003.65 \mathrm{~km}^{2}$ (3-m LiDAR) in the Lower St. John River Watershed. This result is not surprising, since high-resolution LiDAR DEM can generate more detailed slope grid and pick up subtle topographic changes on the bare Earth, while low-resolution LiDAR DEMs and SRTM DEM will eliminate subtle 
topographic transitions when converting into slope grids. Given this limitation, only extremely-steep slope areas will be identified from low-resolution slope grids, while less-steep slope areas will remain undetected and thus excluded from steep slope MCZ delineation.

Table 2 Total area (sq km) for each ARA components by DEM resolution

a Lower St. John River Watershed

\begin{tabular}{|c|c|c|c|c|c|c|c|}
\hline $\begin{array}{l}\text { DEM source } \\
\text { and resolution }\end{array}$ & $\begin{array}{l}\text { Basezone } \\
\text { (floodplain) } \\
\text { (wet | non- } \\
\text { wet) }\end{array}$ & $\begin{array}{l}\text { Terraces } \\
\text { (wet | } \\
\text { non-wet) }\end{array}$ & Wetland & $\begin{array}{l}\text { Steep } \\
\text { slope }\end{array}$ & $\begin{array}{l}\text { MCZs } \\
(60-m)\end{array}$ & & \\
\hline SRTM 30-m & 1240.59 & 687.44 & - & 597.36 & 616.77 & 394.62 & \\
\hline LiDAR 30-m & 1452.14 & 881.18 & - & 660.67 & 671.7 & 459.09 & \\
\hline LiDAR 15-m & 1993.14 & 959.43 & - & 821.89 & 802.43 & 395.94 & \\
\hline LiDAR 10-m & 2033.78 & 737.94 & - & 905.70 & 902.72 & 467.23 & \\
\hline LiDAR 5-m & 2625.84 & 504.32 & 244.47 & 157.91 & 1181.33 & 906.85 & 418.82 \\
\hline LiDAR 3-m & 3246.26 & 544.78 & 447.93 & 206.88 & 1370.5 & 1003.6 & 407.39 \\
\hline
\end{tabular}

b Miramichi River Basin

\begin{tabular}{|c|c|c|c|c|c|c|c|}
\hline $\begin{array}{l}\text { DEM source } \\
\text { and resolution }\end{array}$ & $\begin{array}{l}\text { Basezone } \\
\text { (floodplain) } \\
\text { (wet I non- } \\
\text { wet) }\end{array}$ & $\begin{array}{l}\text { Terraces } \\
\text { (wet I } \\
\text { non-wet) }\end{array}$ & Wetland & $\begin{array}{l}\text { Steep } \\
\text { slope }\end{array}$ & $\begin{array}{l}\text { MCZs } \\
(60-m)\end{array}$ & & \\
\hline SRTM 30-m & 1228.72 & 159.14 & - & 653.51 & 542.74 & 196.13 & \\
\hline LiDAR 30-m & 1474.43 & 237.23 & - & 950.78 & 622.03 & 184.49 & \\
\hline LiDAR 15-m & 1816.63 & 187.20 & - & 1004.64 & 726.53 & 170.23 & \\
\hline LiDAR 10-m & 1994.09 & 144.41 & - & 1041.6 & 792.17 & 196.50 & \\
\hline LiDAR 5-m & 2452.88 & 94.84 & 220.31 & 52.36 & 1200.37 & 778.82 & 178.12 \\
\hline LiDAR 3-m & 3075.09 & 163.08 & 258.08 & 57.07 & 1337.34 & 883.67 & 196.03 \\
\hline
\end{tabular}

\subsection{High-Spatial Resolution LiDAR DEM Smoothing}

The FPDEMS method effectively subdued topographic complexity at local scales in both 3-m and 5-m LiDAR DEMs, while retaining the complexity of macro-scale landforms (Fig. 13). The rough appearance of raw high-resolution LiDAR DEMs was successfully removed, while the boundaries of important topographic features (i.e., channel edges) were preserved (Fig. 13 c, d). Moreover, the run time of the 
FPDEMS method is acceptable- 5 minutes and 25 minutes for 5-m LiDAR DEM and 3-m LiDAR DEM, respectively, in both study watersheds-with the aid of a high-end laptop (i.e., 6-core $2.2 \mathrm{GHz}$ processor and 24 GB of memory).

Smoothed high-resolution LiDAR DEMs generated more realistic creek and headwater basezones in comparison to raw LiDAR DEMs (Fig. 14). Raw high-resolution LiDAR DEMs exhibited many cut-off planforms or so-called "padi terraces" at the local scale (Fig. 13). These areas are typical of closed contours where all the surrounding pixels exhibit the same elevation and slope value. Accordingly, all pixels inside the closed contours were assigned the same cost distance value and thus the determined cost thresholds did not necessarily cut off accurate basezone extents for creeks and headwaters.

Through visual inspection, the widths of creeks and headwaters modelled by raw high-resolution LiDAR DEMs appear much greater than the general widths of creek and headwater floodplains, reported as ranging from $5 \mathrm{~m}$ to $50 \mathrm{~m}$ (Benda et al. 2007). Furthermore, many creek and headwater basezones are connected to each other and cover a large portion of the watersheds, thereby magnifying the problem of overprediction (Fig. 11, Fig. 12). The FPDEMS method successfully removed these cut-off planforms; pixels therefore received accurate cost distance values given their location to source cells. As a result, the determined cost distance thresholds effectively cut off areas that are not likely to be dynamically linked to creeks or headwaters (Fig. 14).

The area of floodplain derived from smoothed DEM was considerably smaller than those derived from raw LiDAR DEMs. For instance, in the Lower St. John River Watershed, total floodplain areas (wet and non-wet) derived from raw and smoothed 5-m LiDAR DEMs are approximately $3130.16 \mathrm{~km}^{2}$ and 1552.98 $\mathrm{km}^{2}$, respectively, a decrease of $1577.18 \mathrm{~km}^{2}(>50 \%)$ (Table 3). The area of riparian wetland shows a similar trend in both study watersheds: in the Miramichi River Basin, the area of riparian wetland decreases from $1200.37 \mathrm{~km}^{2}$ to $889.88 \mathrm{~km}^{2}$ (25\%) with smoothing of 5-m LiDAR DEM (Table 3 ). This result is not surprising, since the FPDEMS algorithm removed many cut-off planforms (i.e., areas of low slope likely to be misidentified as riparian wetlands). An increasing trend in area of steep slope with smoothing can be found in both watersheds (Table 3), also explained by removal of cut-off planforms.

Table 3 A comparison of raw DEM-derived ARA and smoothed DEM derived ARA (in sq km)

a Lower St. John River Watershed 


\begin{tabular}{|c|c|c|c|c|c|c|c|}
\hline $\begin{array}{l}\text { DEM } \\
\text { resolution }\end{array}$ & $\begin{array}{l}\text { Floodplain } \\
\text { (wet) (non- } \\
\text { wet) }\end{array}$ & $\begin{array}{l}\text { Terraces } \\
\text { (wet) (non- } \\
\text { wet) }\end{array}$ & Wetland & $\begin{array}{l}\text { Steep } \\
\text { slope }\end{array}$ & $\begin{array}{l}\text { MCZs } \\
(60-m)\end{array}$ & & \\
\hline $5-m$ & 2625.84 & 504.32 & 244.47 & 157.91 & 1181.33 & 906.85 & 418.82 \\
\hline 3-m & 3246.26 & 544.78 & 447.93 & 206.88 & 1370.5 & 1003.65 & 407.39 \\
\hline $\begin{array}{l}\text { smoothed } \\
5-m\end{array}$ & 1314.33 & 238.65 & 227.21 & 170.74 & 826.17 & 992.02 & 529.36 \\
\hline $\begin{array}{l}\text { smoothed } \\
3-\mathrm{m}\end{array}$ & 1415.77 & 281.91 & 215.94 & 132.01 & 1008.62 & 1034.96 & 531.4 \\
\hline
\end{tabular}

b Miramichi River Basin

\begin{tabular}{|c|c|c|c|c|c|c|c|}
\hline $\begin{array}{l}\text { DEM } \\
\text { resolution }\end{array}$ & $\begin{array}{l}\text { Floodplain } \\
\text { (wet) (non- } \\
\text { wet) }\end{array}$ & $\begin{array}{l}\text { Terraces } \\
\text { (wet) (non- } \\
\text { wet) }\end{array}$ & Wetland & $\begin{array}{l}\text { Steep } \\
\text { slope }\end{array}$ & $\begin{array}{l}\text { MCZs (60- } \\
\mathrm{m})\end{array}$ & & \\
\hline $5-m$ & 2452.88 & 94.84 & 220.31 & 52.36 & 1200.37 & 778.82 & 178.12 \\
\hline $3-m$ & 3075.09 & 163.08 & 258.08 & 57.07 & 1337.34 & 883.67 & 196.03 \\
\hline $\begin{array}{l}\text { smoothed } \\
5-m\end{array}$ & 1235.28 & 39.37 & 166.84 & 46.3 & 889.88 & 851.3 & 218.86 \\
\hline $\begin{array}{l}\text { smoothed } \\
3-\mathrm{m}\end{array}$ & 1289.5 & 51.1 & 205.73 & 46.58 & 967.37 & 886.08 & 214.18 \\
\hline
\end{tabular}

\subsection{Effects of DEM Error on Topographic and Hydrologic Modelling}

\subsubsection{DEM error and uncertainty}

RMSE values increased with decreasing resolution of resampled LiDAR DEMs, indicating lower accuracy of lower- as compared to higher-resolution LiDAR DEMs, with the same trend found in both study watersheds. For instance, in the Lower St. John River Watershed, RMSEs range from $0.2588 \mathrm{~m}$ to 1.0281 $\mathrm{m}$, increasing for all resampled LiDAR DEMs as the resolution decreases from 3-m to 30-m (Table 4). Additionally, RMSEs for SRTM 30-m DEMs are significantly higher than for resampled 30-m LiDAR DEMs, by approximately 4 times in both study watersheds, indicating overall low accuracy of SRTM DEMs as compared to LiDAR DEMs of the same resolution. It is also interesting to note that RMSEs of smoothed high-resolution DEMs and raw high-resolution DEMs differ only marginally (Table 4), indicating the ability of the FPDEMS method to preserve original elevation values.

Table 4 RMSE of different DEM datasets 


\begin{tabular}{|lll|}
\hline & Lower St. John River Watershed & Miramichi River Basin \\
\hline & 4.1855 & 3.8066 \\
& 1.0281 & 0.8854 \\
& 0.6132 & 0.6148 \\
& 0.4626 & 0.4539 \\
& 0.3376 & 0.3550 \\
& 0.2588 & 0.2702 \\
& 0.4443 & 0.4509 \\
& 0.3067 & 0.3018 \\
\hline 30-m & & \\
\hline 15-m & & \\
\hline 10-m & & \\
\hline 5-m & & \\
\hline 3-m s-mooth & & \\
\hline
\end{tabular}

\subsubsection{Effects of DEM Error on Topographic Modelling}

Maximum slope values increase dramatically as the resolutions of resampled LiDAR DEMs increase (or RMSE values decrease) (Fig. 15). For example, maximum slope value increases from approximately 60 to 80 degrees as LiDAR DEM resolution increases from 30-m (RMSE $=1.0281)$ to 3-m (RMSE= 0.2588) in the Lower St. John River Watershed (Fig. 15). Because smoothed and raw high-resolution LiDAR DEMs have similar RMSE values, the ranges of their slope values are similar to each other (Fig. 15), reflecting an ideal characteristic of the FPDEMS in terms of important topographic feature preservation. The inner value distributions of slope grids, however, differ between smoothed and raw high-resolution LiDAR DEMs (Fig. 15). For instance, in both study watersheds, interquartile ranges (i.e., 25th to 75th quartiles) of derived slopes from smoothed high-resolution LiDAR DEMs are smaller than those from raw high-resolution LiDAR DEMs, as the FPDEMS method removed several planforms with low-slope values.

\subsubsection{Effects of DEM Error and Uncertainty on Hydrologic Modelling}

TMIs derived from DEMs with low RMSEs tend to follow a normal distribution; in contrast, TMIs derived from DEMs with high RMSEs are positively skewed, though it is difficult to comment on the accuracy of one distribution over another in the absence of reference data. In the Miramichi River Basin, for instance, the difference between median (744) and mean (747) values of 5-m LiDAR DEM (RMSE $=0.3550$ ) derived 
TMI is 3; differences between mean and median TMI value increase to 162.32 and 217.89 , respectively, for the TMls derived from 30-m LiDAR DEM (RMSE = 0.8854) and 30-m SRTM DEM (RMSE = 3.8066) (Table 5). A declining trend can be seen in both mean and median TMI values as DEM RMSEs increase; a similar trend can be found in both study watersheds (Table 5), indicating that more pixels received lower TMI values in the low-quality DEM-based parallel analyses, possibly explaining in part the underprediction issue of riparian wetland. Additionally, the DEM smoothing algorithm lowered the mean and median values of TMI in both study watersheds, which partially explains the declining trend in the area of riparian wetland shown in the Table 3, as more pixels received lower TMI values and were considered dry areas.

Table 5 Distribution of different DEM-derived TMls

\begin{tabular}{|c|c|c|c|c|c|c|}
\hline & $\begin{array}{l}\text { Lower St. John River } \\
\text { Watershed }\end{array}$ & $\begin{array}{l}\text { Miramichi River } \\
\text { Basin }\end{array}$ & & & & \\
\hline & Mean & Median & $\begin{array}{l}\text { Std. } \\
\text { Dev }\end{array}$ & Mean & Median & $\begin{array}{l}\text { Std. } \\
\text { Dev }\end{array}$ \\
\hline $\begin{array}{l}\text { SRTM } \\
30-m\end{array}$ & 109.87 & -127 & 1132.13 & 87.89 & -130 & 1066.91 \\
\hline $30-m$ & 396.9 & 140 & 1335.21 & 294.32 & 132 & 1120.74 \\
\hline $15-m$ & 491.51 & 309 & 1213.4 & 432.74 & 341 & 945.1 \\
\hline $10-m$ & 504.27 & 426 & 971.19 & 514.63 & 455 & 912.5 \\
\hline $5-m$ & 762.74 & 721 & 990.53 & 747 & 744 & 908.28 \\
\hline 3-m & 1037.87 & 1006 & 1001.8 & 991.37 & 1005 & 900.09 \\
\hline $\begin{array}{l}\text { 5-m } \\
\text { smooth }\end{array}$ & 585.06 & 567 & 867.53 & 413.19 & 410 & 654.09 \\
\hline $\begin{array}{l}\text { 3-m } \\
\text { smooth }\end{array}$ & 767.53 & 734 & 891.33 & 447.06 & 440 & 629.36 \\
\hline
\end{tabular}

\subsection{Accuracy-Efficiency Trade-Off Analysis}

\subsubsection{Accuracy Assessment}

The correlation coefficients $\left(\mathrm{R}^{2}\right)$ between Kappa Coefficient and RMSE in the watersheds are approximately 0.6 and 0.75 , indicating that the overall accuracy (i.e., Kappa Coefficient) of ARA results is subject to the input DEM quality (i.e., RMSE) (Fig. 16). The correlation between RMSEs and Kappa Coefficients of raw high-resolution LiDAR-DEM derived ARAs, however, does not fit this trend (Fig. 16), as the creek and headwater basezone extents are grossly inaccurate due to over-detailed topographic representation (Fig. 14). In addition to the reference ARA, the 5-m smoothed LiDAR DEM-derived ARAs achieved highest overall accuracies in final ARA output, with Kappa Coefficients near 0.8 in both study watersheds (Table 6). Since the SRTM-DEM has the highest RMSE value, the Kappa Coefficients of 30-m 
SRTM-DEM derived ARAs are smaller than those of 30-m LiDAR DEM derived ARAs in both study watersheds, reflecting the weak ability of SRTM-DEM in terms of ARA delineation as compared to LiDAR DEM of the same spatial resolution.

Table 6 Kappa Coefficients of different DEM-derived ARAs

\begin{tabular}{|c|c|c|}
\hline & Kappa Coefficient & \\
\hline & Lower St. John River Watershed & Miramichi River Basin \\
\hline SRTM 30-m & 0.5187 & 0.4564 \\
\hline $30-m$ & 0.5952 & 0.5903 \\
\hline 15-m & 0.6251 & 0.6611 \\
\hline $10-m$ & 0.6647 & 0.6789 \\
\hline $5-m$ & 0.6387 & 0.6092 \\
\hline $3-m$ & 0.5252 & 0.4822 \\
\hline 5-m smooth & 0.7884 & 0.8247 \\
\hline 3-m smooth & 1.0000 & 1.0000 \\
\hline
\end{tabular}

\subsubsection{Efficiency Assessment}

Using consistent computational power (i.e., laptop with 6-core $2.2 \mathrm{GHz}$ processor and $24 \mathrm{~GB}$ of memory), there are moderate differences in total runtime for key geoprocessing tools among low-resolution LiDAR DEM-based analyses (Table 7). In contrast, a significant increase in runtime is evident once LiDAR DEM spatial resolution reaches 5-m. Accordingly, the 5-m LiDAR DEM can be assumed as a turning point in runtime in both study watersheds. The overall accuracy of 5-m LiDAR DEM derived ARA, however, is relatively low due to the inaccurate delineation of creek and headwater basezones. It is also interesting to note that the DEM smoothing algorithm saves $~ 30 \%$ in data processing time by smoothing noisy microtopographic detail. For instance, in the Miramichi River Basin, total runtime decreases from 591 to 414 minutes for raw 3-m and smoothed 3-m DEM, respectively (Table 7).

Table 7 Runtime (minutes) of key geoprocessing tools 


\begin{tabular}{|c|c|c|c|c|}
\hline & $\begin{array}{l}\text { Lower St. John River } \\
\text { Watershed }\end{array}$ & $\begin{array}{l}\text { Miramichi River } \\
\text { Basin }\end{array}$ & & \\
\hline & Batch cost distance & $\begin{array}{l}\text { Flow } \\
\text { accumulation }\end{array}$ & $\begin{array}{l}\text { Batch cost } \\
\text { distance }\end{array}$ & $\begin{array}{l}\text { Flow } \\
\text { accumulation }\end{array}$ \\
\hline $\begin{array}{l}\text { SRTM 30- } \\
\text { m }\end{array}$ & N 3 mins9s & 2 mins & 4 mins & 2 mins \\
\hline $30-\mathrm{m}$ & 3 mins & 2 mins & 4 mins & 2 mins \\
\hline $15-m$ & 9 mins & 6 mins & 12 mins & 7 mins \\
\hline 10-m & 25 mins & 12 mins & 25 mins & 13 mins \\
\hline $5-m$ & 152 mins & 38 mins & 141 mins & 32 mins \\
\hline 3-m & 521 mins & 80 mins & 516 mins & 75 mins \\
\hline $\begin{array}{l}5-m \\
\text { smooth }\end{array}$ & 89 mins & 46 mins & 73 mins & 99 mins \\
\hline $\begin{array}{l}3-m \\
\text { smooth }\end{array}$ & 277 mins & 103 mins & 261 mins & 153 mins \\
\hline
\end{tabular}

\subsubsection{Accuracy-Efficiency Trade-Off}

The accuracy-efficiency curve was created using runtime and Kappa Coefficient as variables. A strong correlational relationship was detected between the accuracy and efficiency variables, with the coefficient greater than 0.9 in both study watersheds (Fig. 17). The inflection point exists at the 5-m smoothed LiDAR DEM, with Kappa Coefficient at approximately 0.8 while data processing time remains low (Fig. 17). As indicated by Cohen (1960), Kappa Coefficient greater than "0.8" represents perfect agreement between delineation and observation (i.e., 3-m smoothed DEM-derived ARA). The 5-m smoothed LiDAR DEMs therefore achieves high accuracy in ARA results. Although 3-m smoothed LiDAR DEMs can achieve the most accurate ARA results in both watersheds, runtimes to process 3-m and 5-m smoothed LiDAR DEMs differ greatly (by almost 3 times), indicating that 3-m smoothed LiDAR DEM is less efficient than 5-m smoothed LiDAR DEM. To balance accuracy and efficiency, 5-m smoothed LiDAR DEMs are recommended for future ARA delineations, especially across large spatial extents or multiple watersheds.

This recommendation should be applied carefully, however, since the accuracy-efficiency trade-off analysis is not without limitations. Although it has been well acknowledged in the literature that highresolution LiDAR DEMs can achieve higher accuracy in results in terms of floodplain delineation (Zhao et al., 2010, Tan et al., 2018), there is no reference literature to demonstrate that ARA studies also fit this trend. The reliability of the reference ARA (i.e., 3-m smoothed LiDAR DEM derived ARA) needs further examination; and, the result of trade-off analyses may differ if the reference ARA changes. Nevertheless, the accuracy assessment framework provides a unique lens through which to effectively assess ARA accuracy. In future studies, ground reference surveys are recommended to verify and enhance the reliability of the reference ARA. Additionally, ground reference surveys can enhance the accuracy of RMSE 
values calculated for different DEMs by replacing the reference elevation values extracted from 1-m LiDAR DEM with elevation values measured in the field.

The RMSE was applied to indicate DEM quality in this study, which assumes error to be aspatial. Error related to the DEM, however, varies spatially and cannot be sufficiently assessed by a global metric such as RMSE (Hawker et al. 2018). Indeed, scientists have observed that local DEM error can be large and spatially correlated, though global RMSE is small (Holmes et al. 2000, Bater and Coops 2009), and thus it is possible that the optimal DEM resolution for ARA delineation is landscape specific. More comprehensive ways to consider DEM error from a spatial perspective (or landscape perspective), such as Classification and Regression Tree (CART) analysis (Bater and Coops 2009) and Monte Carlo-based Sequential Gaussian Simulation (SGS) analysis (Fereshtehpour and Karamouz 2018), is therefore required. Such analyses can allow the DEM user to better understand the relationship between DEM quality and accuracy of ARA. Optimal DEM for ARA delineation may also vary with differences in landscape features, and thus, ideally, or eventually, it is anticipated that optimal DEM will be identified for specific landscape contexts in future applications.

\section{Conclusion}

This study (1) tested whether high-resolution LiDAR DEM can achieve floodplain and terrace separation; (2) verified the applicability of a novel DEM smoothing algorithm on ARA delineation; (3) analyzed the relationship between DEM qualities and topographic and hydrologic modelling uncertainties; and (4) identified optimal input DEM for future ARA delineation across large regions by assessing various DEMs for ARA output accuracy and data processing efficiency. Results show that a refined ARA framework based on high-resolution LiDAR DEM was successful at floodplain and terrace separation, representing an important methodological improvement. Comparison of ARA outputs from various input DEMs reveals differences in performance of DEMs on ARA delineation, suggesting that high-resolution LiDAR-DEM can more precisely model the extent of riparian basezone and steep slope areas and detect areas of overlap between riparian basezone and riparian wetland, which are considered to be of conservation value. Analyzed topographic and hydrologic modelling uncertainties were shown to be subject to input DEM quality, suggesting that high-quality input DEM can reduce the topographic and hydrologic modelling uncertainties and enhance ARA output accuracy. Additionally, the selected FPDEMS algorithm was found to be successful at smoothing the high-resolution LiDAR DEM surface roughness caused by over-detailed topographic representation at local spatial scales, while preserving topographic and hydrologic features important to accurate ARA delineation. Finally, the accuracy-efficiency tradeoff analysis suggests that 5$m$ smoothed LiDAR DEM represents the optimal DEM for future ARA studies, especially those applied across multiple watersheds or large study sites.

The findings of this study address important gaps and needed refinements in ARA methodologies of use to researchers and practitioners concerned with watershed and riparian conservation and management. Yet, important questions remain about the reliability of the reference ARA applied for the accuracy assessment and the identification of landscape-specific optimal input DEMs. Further analyses are needed 
to enhance the reliability of the reference dataset for accuracy assessment and identify optimal input DEM for specific landscape contexts.

\section{Declarations}

Funding: The financial support of this study was received in the form of graduate scholarships awarded to S.M., including Dalhousie University's Faculty of Graduate Studies scholarship, Colin Stewart Award, and Neil Munro award.

Conflicts of interest: The authors declare no conflicts of interest.

Availability of data and material: Data used in this study can be downloaded from http://www.snb.ca/geonb1/e/DC/catalogue-E.asp

Code availability: Not applicable

Ethics approval: Not applicable

Consent to participate: Not applicable

Consent for publication: Not applicable

Authors' contributions: S.M. was involved in the study design, acquired and analyzed geospatial data, and wrote the main manuscript text. K.F.B led the research supervision, was involved in the study design, and made substantial contributions to manuscript preparation. P.N. and C.S.G. were involved in research supervision, study design, and manuscript preparation.

\section{References}

Bater, C. W., and Coops, N. C. (2009). Evaluating error associated with lidar-derived DEM interpolation. Computers \& Geosciences, 35(2), 289-300. https://doi.org/10.1016/j.cageo.2008.09.001

Benda. L., Hassan. A.M., Church. M., May. L.C. (2007). Geomorphology of Steep land Headwaters: The Transition from Hillslopes to Channels. Journal of the American Water Resources Association.41(4): 835851. https://doi.org/10.1111/j.1752-1688.2005.tb03773.x

Cohen, J. (1960). A coefficient of agreement for nominal scales. Educational and psychological measurement, 20(1), 37-46. https://doi.org/10.1177/001316446002000104 Environmental Law Institute. (2003). Conservation Thresholds for Land Use Planners. Washington D.C. Retrieved from: https://www.eli.org/sites/default/files/eli-pubs/d13-04.pdf

Fereshtehpour, M., and Karamouz, M. (2018). DEM resolution effects on coastal flood vulnerability assessment: Deterministic and probabilistic approach. Water Resources Research, 54, 4965-4982. https://doi.org/10.1029/2017WR022318 
Foody, G. M. (2002). Status of land cover classification accuracy assessment. Remote sensing of environment, 80(1), 185-201. https://doi.org/10.1016/S0034-4257(01)00295-4

Goyal, M.K., Panchariya, V.K., Sharma, A. et al. Comparative Assessment of SWAT Model Performance in two Distinct Catchments under Various DEM Scenarios of Varying Resolution, Sources and Resampling Methods. Water Resour Manage 32, 805-825 (2018). https://doi.org/10.1007/s11269-017-1840-1

Hawker, L., Bates, P., Neal, J., \& Rougier, J. (2018). Perspectives on digital elevation model (DEM) simulation for flood modeling in the absence of a high-accuracy open access global DEM. Frontiers in Earth Science, 6, 233. https://doi.org/10.3389/feart.2018.00233

Holmes, K. W., Chadwick, O. A., and Kydriakidis, P. C. (2000). Error in a USGS 30- meter digital elevation model and its impact on terrain modelling. Journal of Hydrology. 233, 154-173. https://doi.org/10.1016/S0022-1694(00)00229-8

Ihart B.L.,Verry E.S. and Palik B.J. (2000). Defining Riparian Areas. Forest and the Riparian zone 7-13. Kuglerová, L., Ågren, A., Jansson, R., \& Laudon, H. (2014). Towards optimizing riparian buffer zones: Ecological and biogeochemical implications for forest management. Forest Ecology and Management, 334, 74-84. https://doi.org/10.1016/j.foreco.2014.08.033

Kuglerová, L., Jyväsjärvi, J., Ruffing, C., Muotka, T., Jonsson, A., Andersson, E., \& Richardson, S. 2020. Cutting Edge: A Comparison of Contemporary Practices of Riparian Buffer Retention Around Small Streams in Canada, Finland, and Sweden. Water Resources Research, 56(9).

https://doi.org/10.1029/2019WR026381

Lin, S., Jing, C., Chaplot, V., Yu, X., Zhang, Z., Moore, N., and Wu, J. (2010). Effect of DEM resolution on SWAT outputs of runoff, sediment and nutrients. Hydrology and Earth System Sciences Discussions, 7(4), 4411-4435. https://doi.org/10.5194/hessd-7-4411-2010

Lindsay.J.B., Francioni. A., and Cockburn. J.M. (2019). LiDAR DEM Smoothing and the Preservation of Drainage Features. Remote Sensing. 11 (16): 1926. https://doi.org/10.3390/rs11161926

Naiman and, R. J., \& Décamps, H. (1997). The Ecology of Interfaces: Riparian Zones. Annual Review of Ecology and Systematics, 28(1), 621-658. National Research Council. (2002). Riparian Areas: Functions and Strategies for Management. Washington, DC: The National Academies Press.

Nussey, P. and Noseworthy, J. (2020). The Active River Area for the Northern Appalachian- Acadian Region of Canada. Nature Conservancy of Canada. Atlantic Regional Office. Fredericton, New Brunswick

Roostaee, M., Deng, Z. (2020) Effects of Digital Elevation Model Resolution on Watershed- Based Hydrologic Simulation. Water Resour Manage 34, 2433-2447. https://doi.org/10.1007/s11269-02002561-0 
Smith, M.P., Schiff, R., Olivero, A. and MacBroom, J.G., (2008). The Active River Area: A Conservation Framework for Protecting Rivers and Streams. The Nature Conservancy, Boston, MA.

Strahler, A.N., (1957). Quantitative Analysis of Watershed Geomorphology. American Geophysical Union Transactions 38:913-920. https://doi.org/10.1029/TR038i006p00913

Suliman, A.H.A., Katimon, A., Darus, I.Z.M. et al. (2016) TOPMODEL for Streamflow

Simulation of a Tropical Catchment Using Different Resolutions of ASTER DEM: Optimization Through Response Surface Methodology. Water Resour Manage 30, 3159-3173. https://doi.org/10.1007/s11269016-1338-2

Tan, M.L., Ramli, H.P. \& Tam, T.H. (2018). Effect of DEM Resolution, Source, Resampling Technique and Area Threshold on SWAT Outputs. Water Resour Manage 32, 4591-4606.

https://doi.org/10.1007/s11269-018-2072-8

Yan.Q., Iwasaki.T., Stumpf.A., Belmont.P., Parker.G., Kuma.P. (2017). Hydro- geomorphological differentiation between floodplains and terraces. Earth Surface Processes and Landforms. 43, 218-228. https://doi.org/10.1002/esp.4234

Zhao, Z., Benoy, G., Chow, T.L. et al. (2010) Impacts of Accuracy and Resolution of Conventional and LiDAR Based DEMs on Parameters Used in Hydrologic Modeling. Water Resour Manage 24, 1363-1380. https://doi.org/10.1007/s11269-009-9503-5

Ziadat, F.M. (2007). Effect of contour intervals and grid cell size on the accuracy of DEMs and slop derivatives. Transactions in GIS 11, 67-81. https://doi.org/10.1111/j.1467-9671.2007.01033.x

\section{Figures}




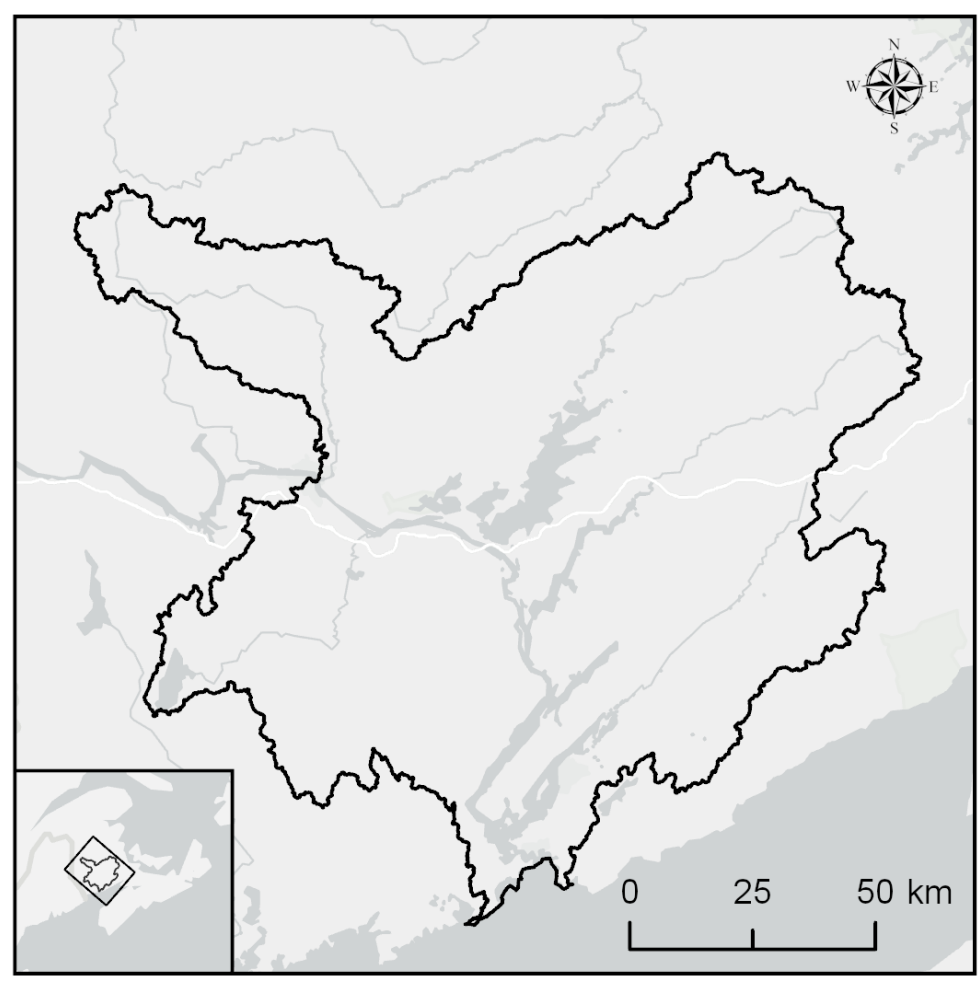

a Lower St. John River Watershed

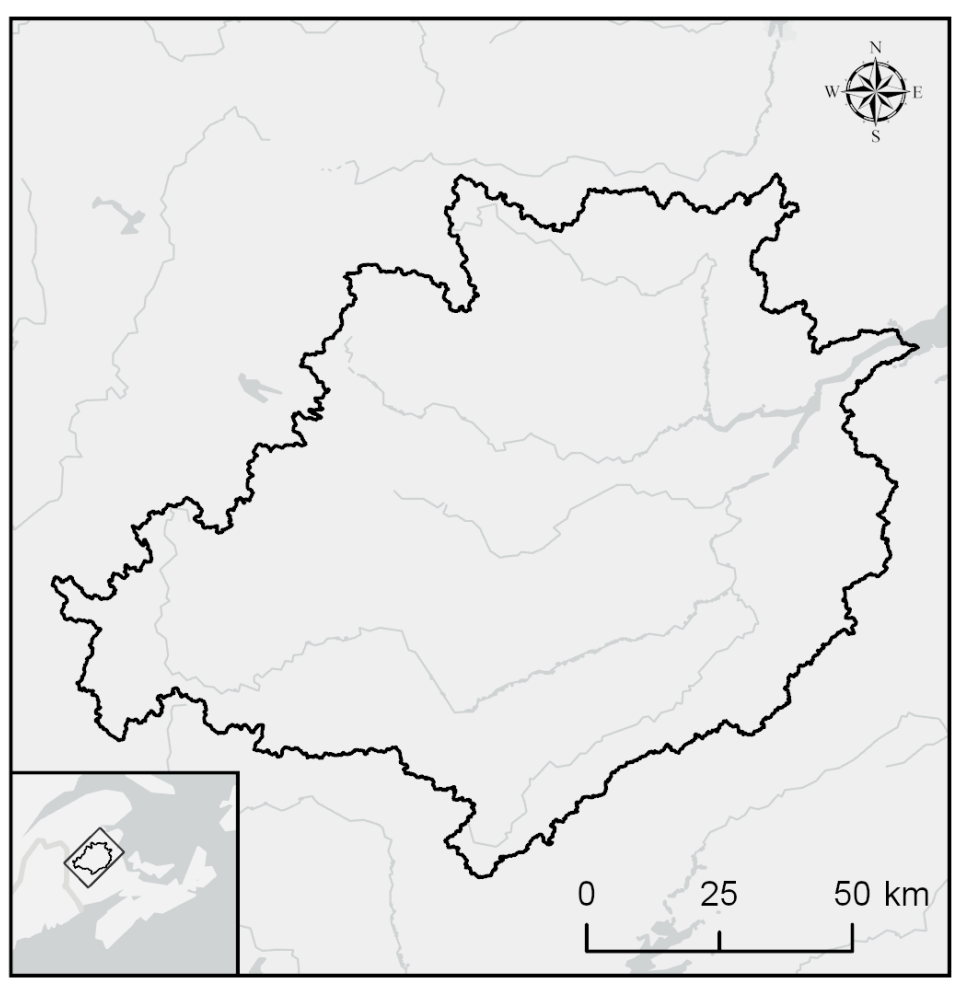

b Miramichi River Basin Watershed

\section{Figure 1}

Study Watersheds 


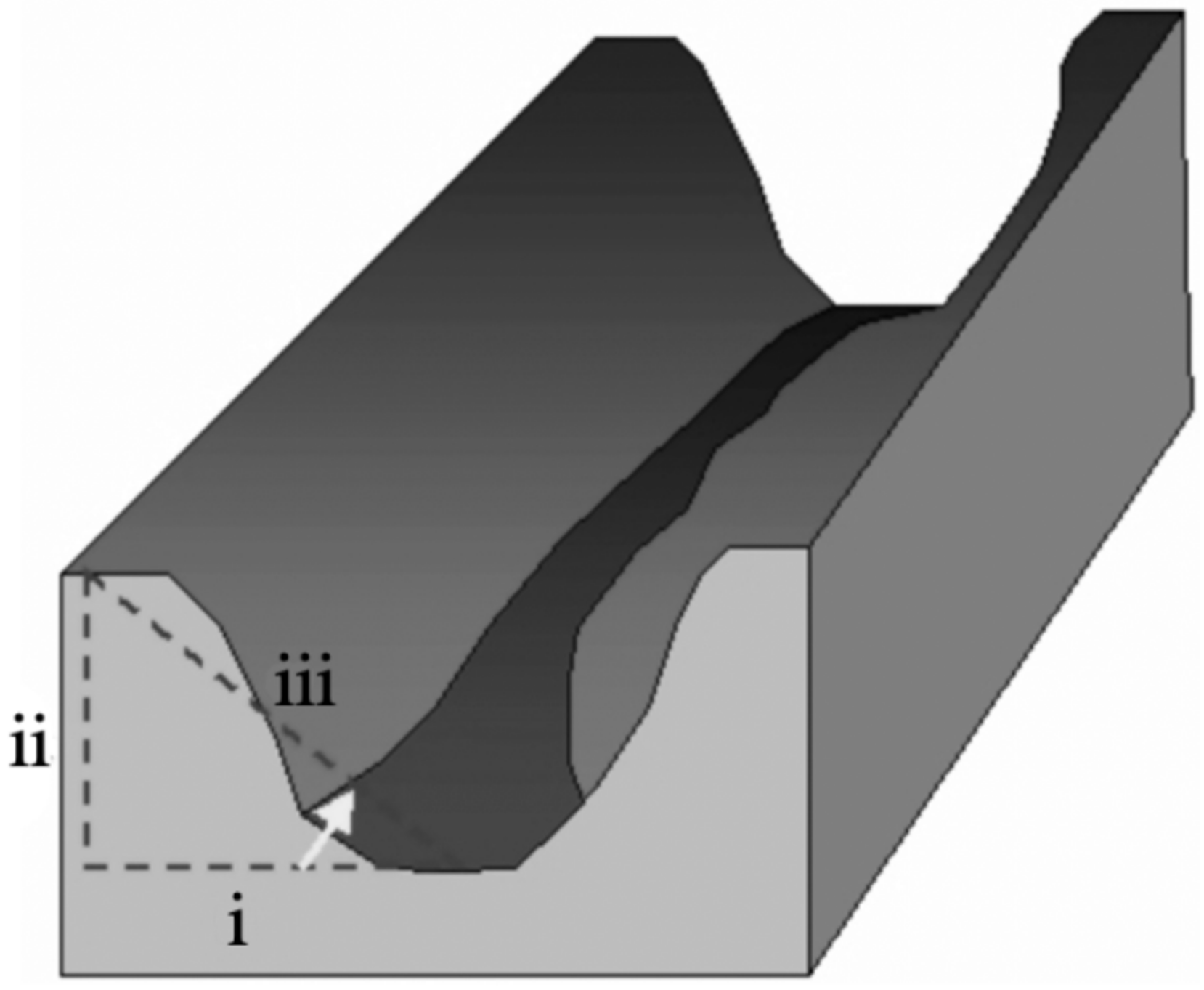

Figure 2

Schematic map shows inputs to cost distance function, including slope (gray arrow) and source (stream). Results are given as a surface of values indicating relative costs (iii) of moving from the watercourse cells up into the valley, accounting for distance (i) and elevation change (ii) 


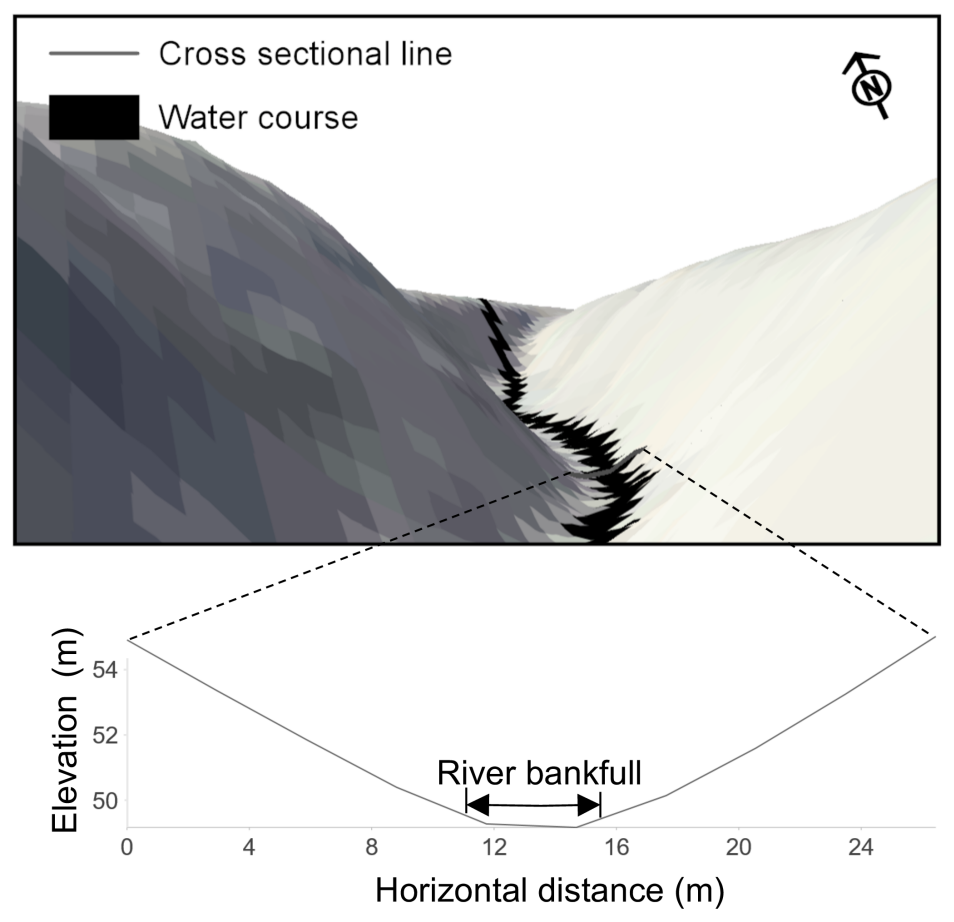

a V-shape valley
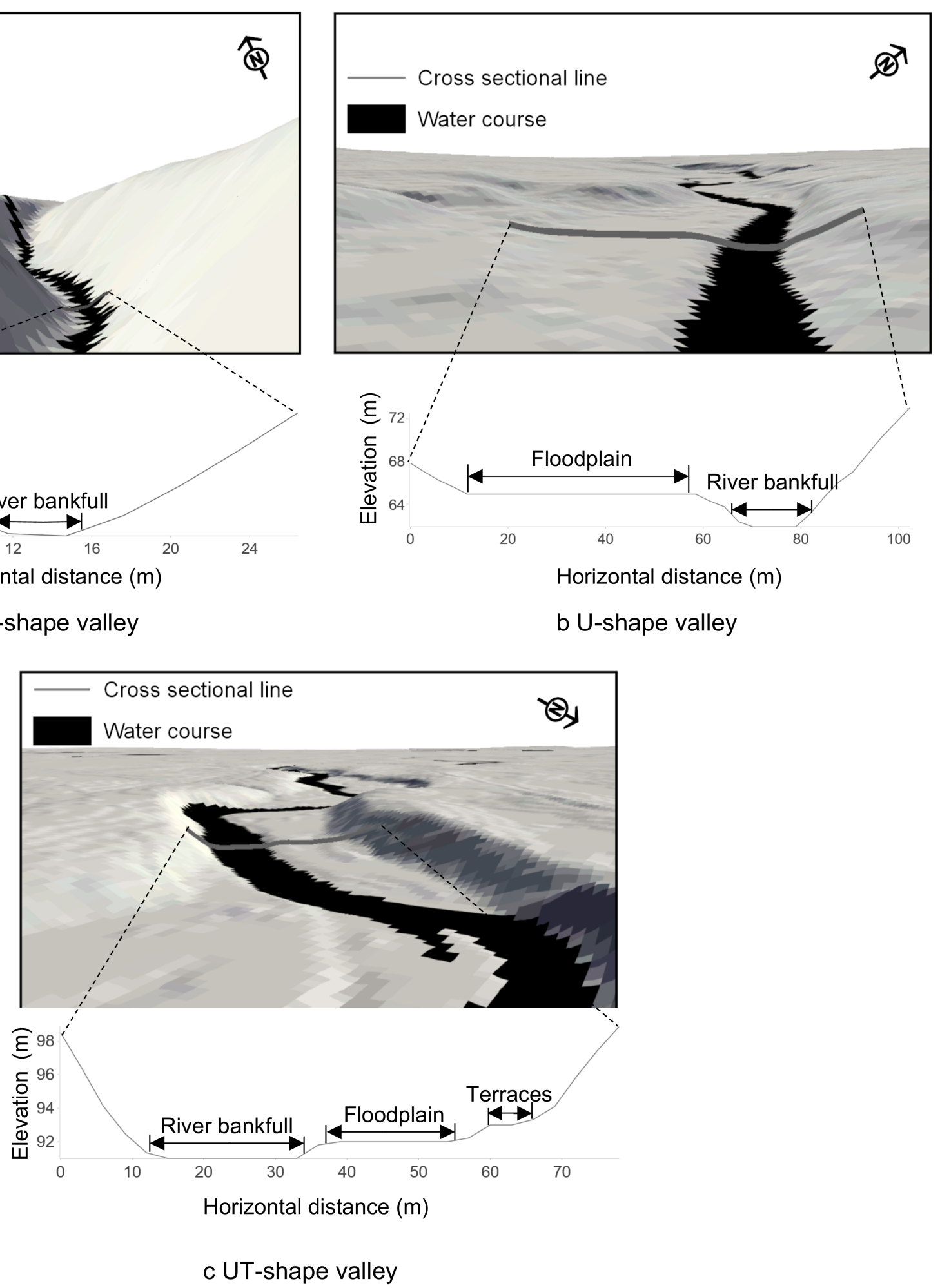

\section{Figure 3}

Illustration of river valley shapes (3-m LiDAR DEM). (a) V-shape valley: floodplain is narrow or absent; (b) U-shape valley: floodplain has clear flat zones, but no terrace; (c) UT-shape Valley: has both floodplain and terraces and hence more than one flat level within the river valley 


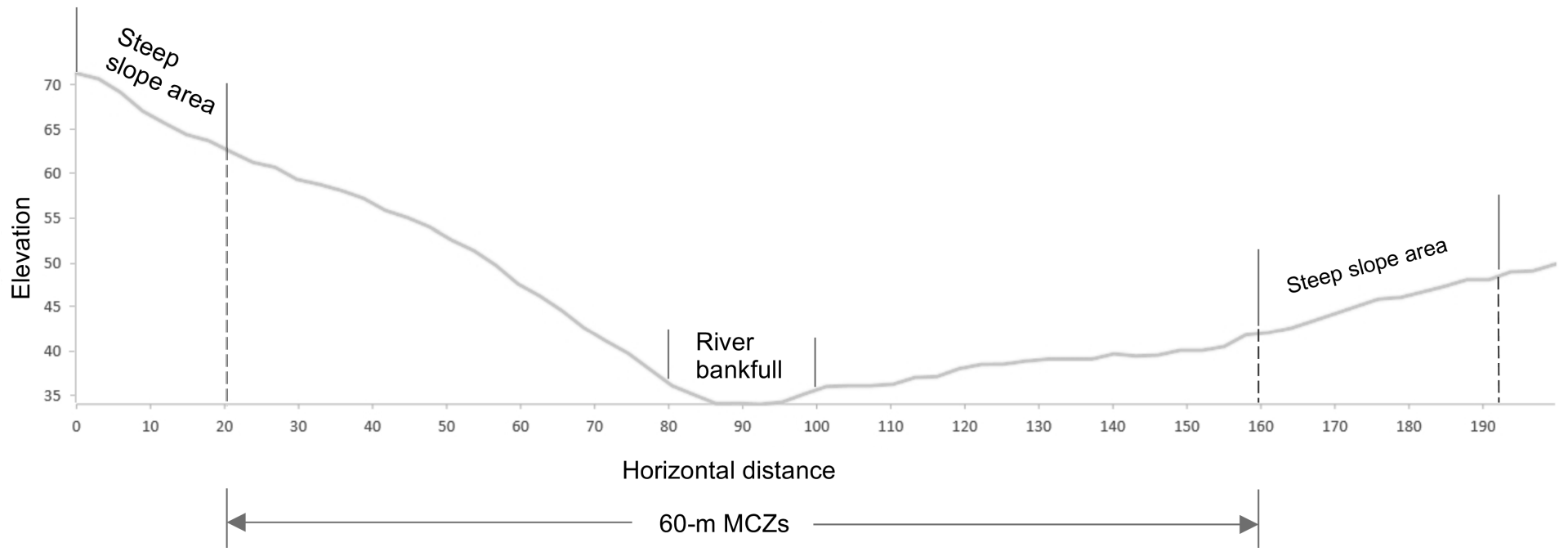

Figure 4

Profile map of confined river valley, illustrating that $60-\mathrm{m}$ buffer is too narrow to incorporate all steep slope areas into MCZs extent

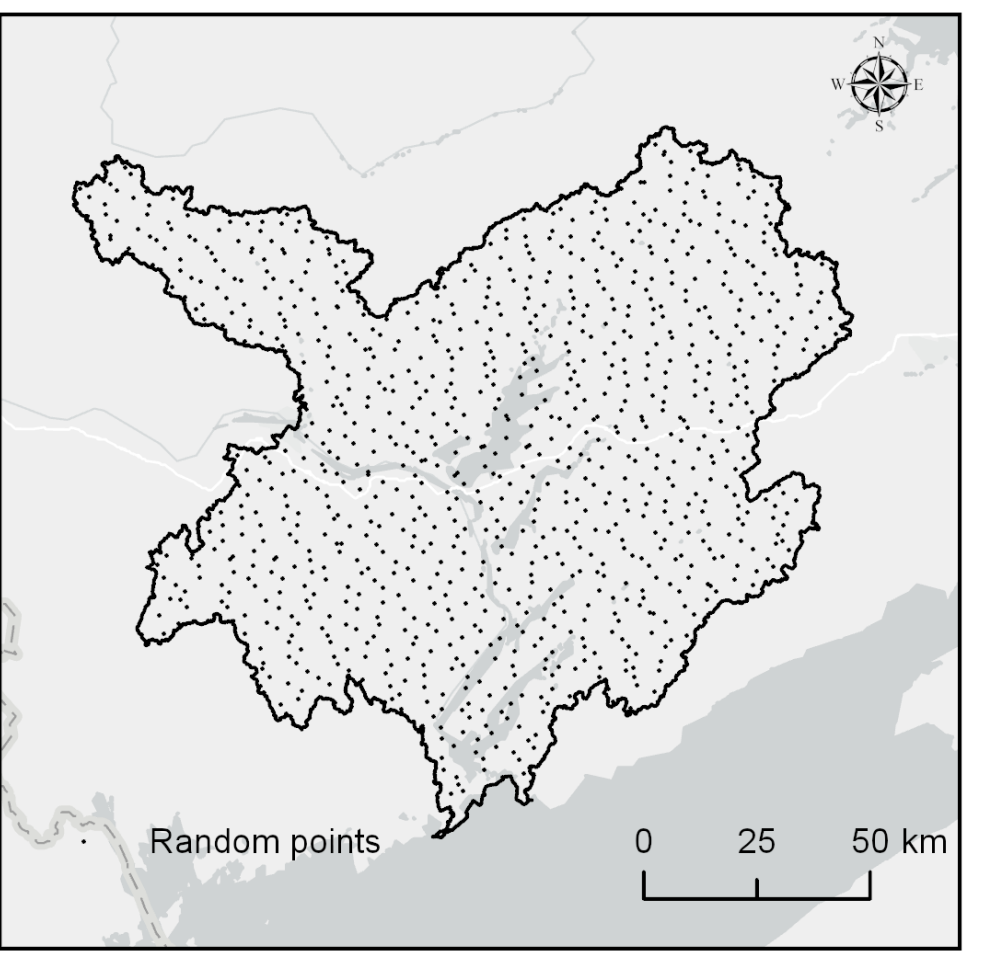

a Lower St. John River Watershed

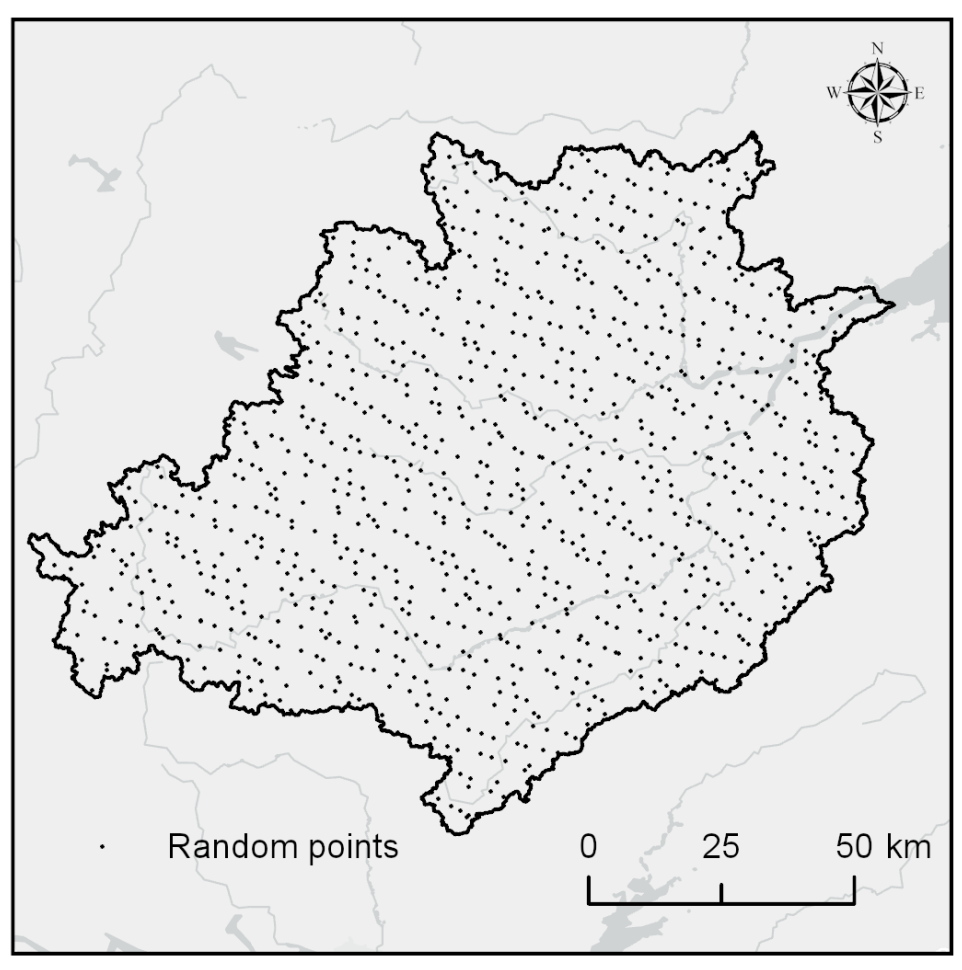

b Miramichi River Basin Watershed

\section{Figure 5}

Ground control point locations in the study watersheds 


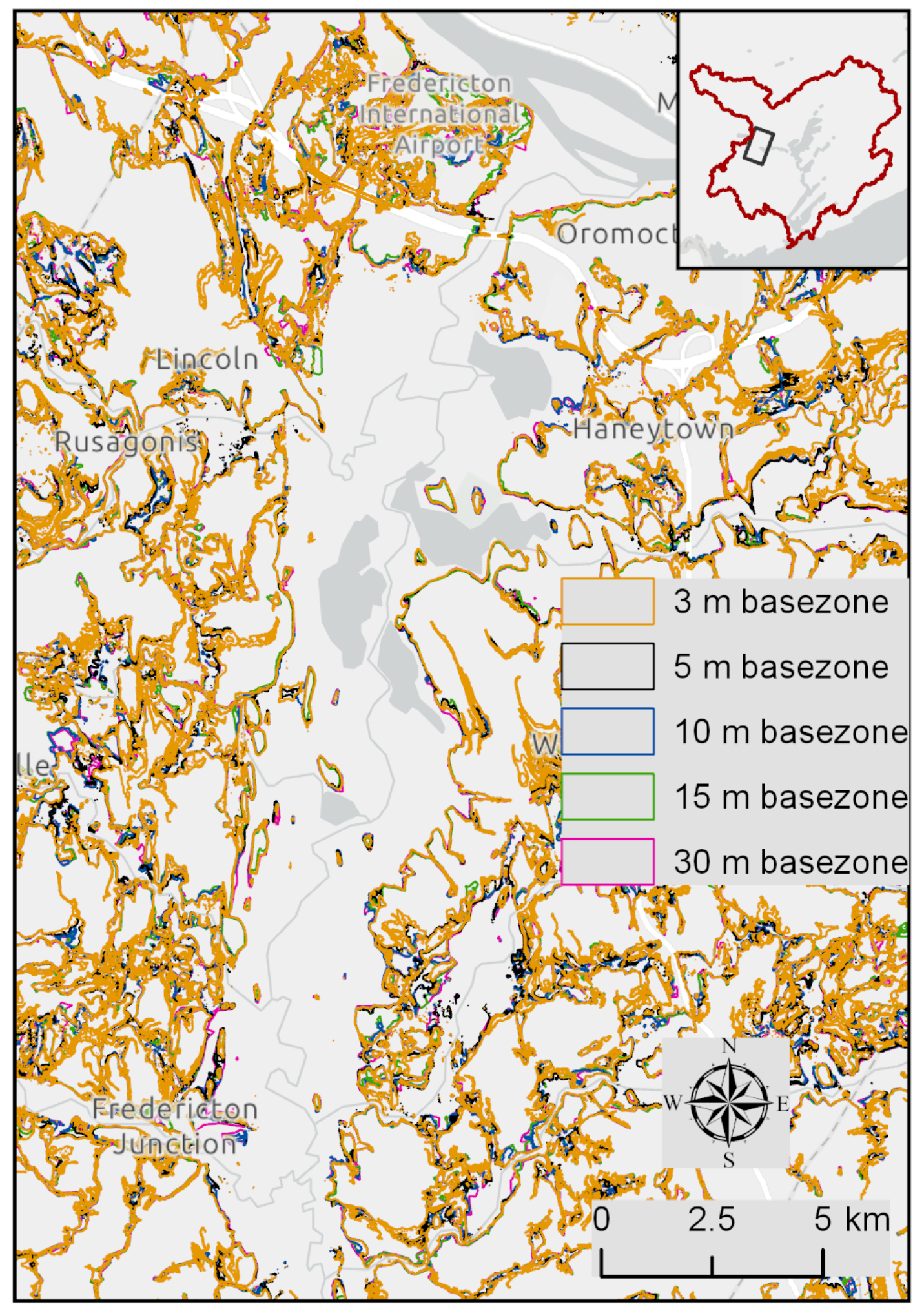

Figure 6

Example area of riparian basezone in the Lower St. John River Watershed. Different colours represent different LiDAR DEM-derived results, illustrating that different LiDAR DEMs have similar abilities to detect riparian basezone extent 


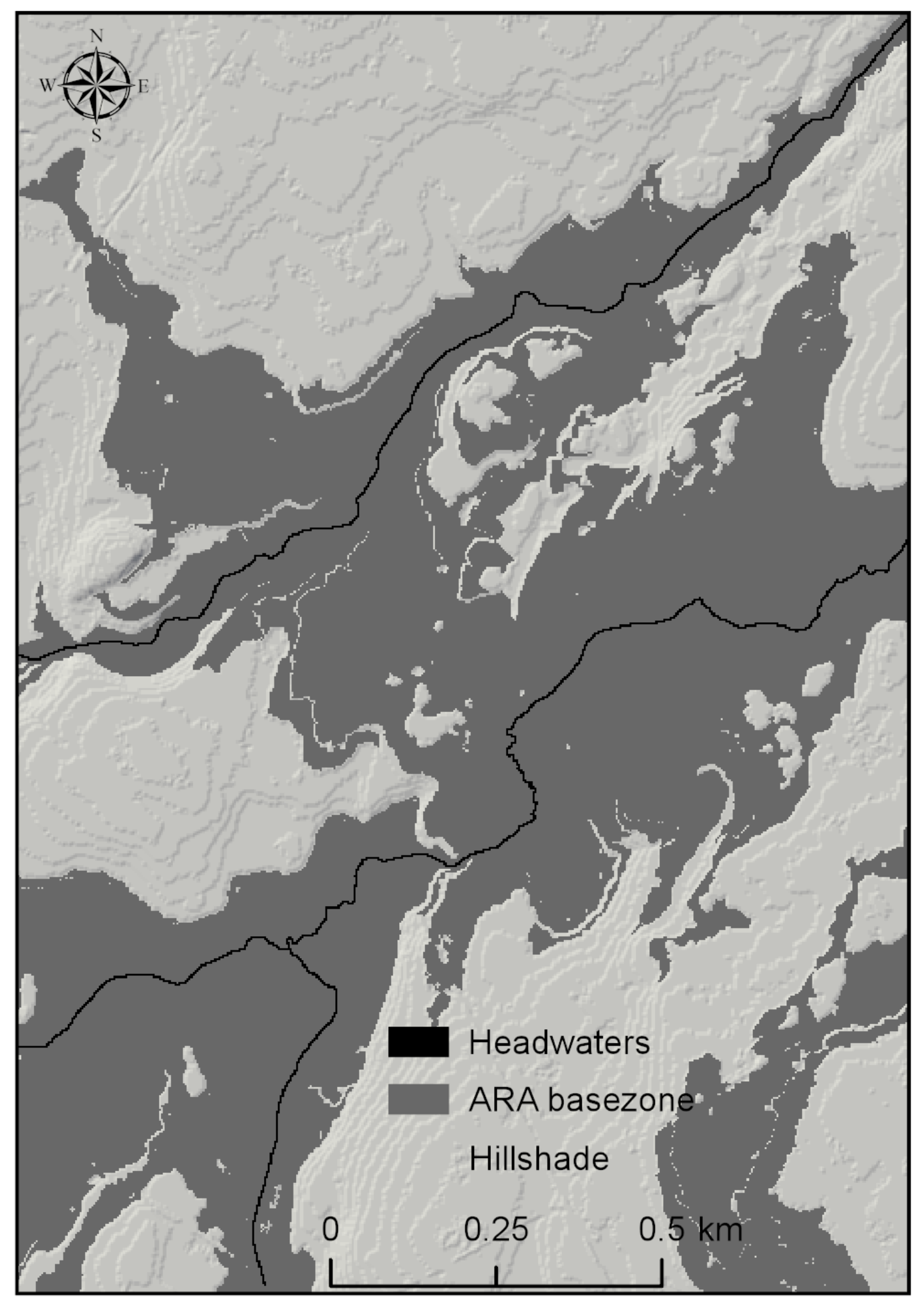

\section{Figure 7}

Example result of terrace and floodplain separation 


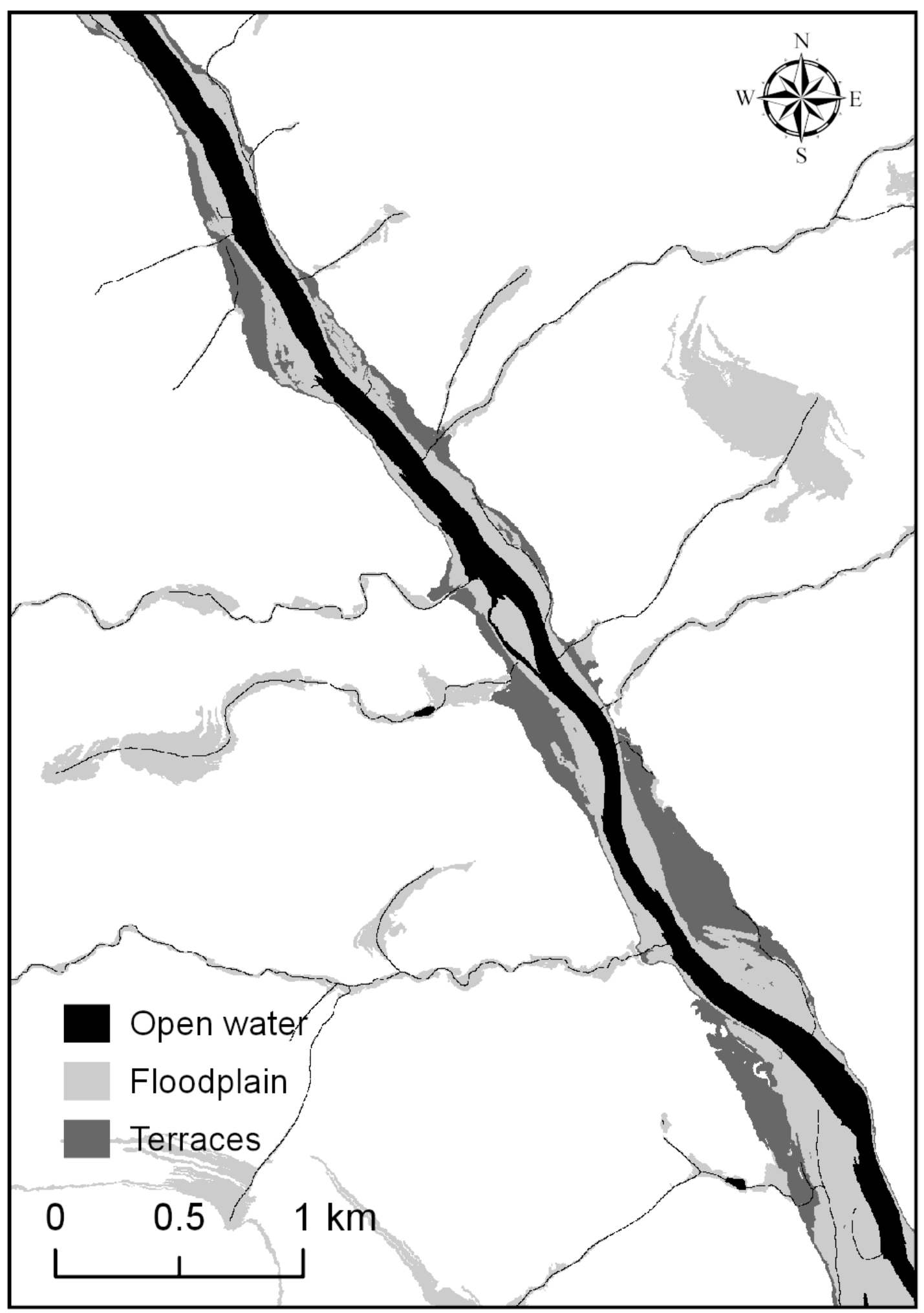

Figure 8

Surface roughness at headwater areas (in 3-m resolution). The rough appearance of Hillshade illustrates several undesirable "steps" across the DEM surface, which causes bias in terrace identification 


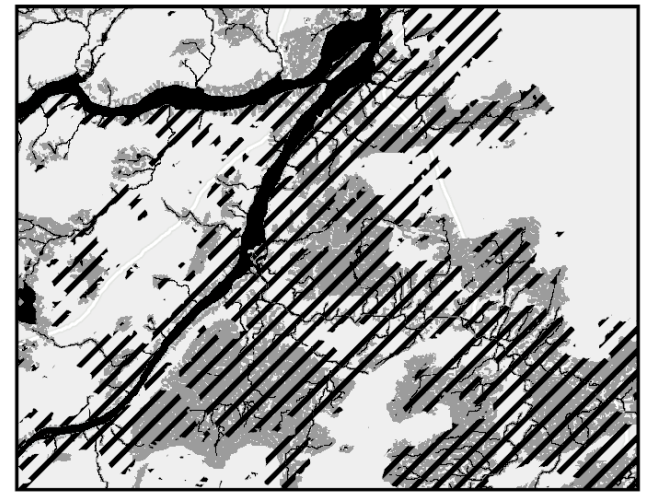

a $30 \mathrm{~m} \mathrm{DEM}$

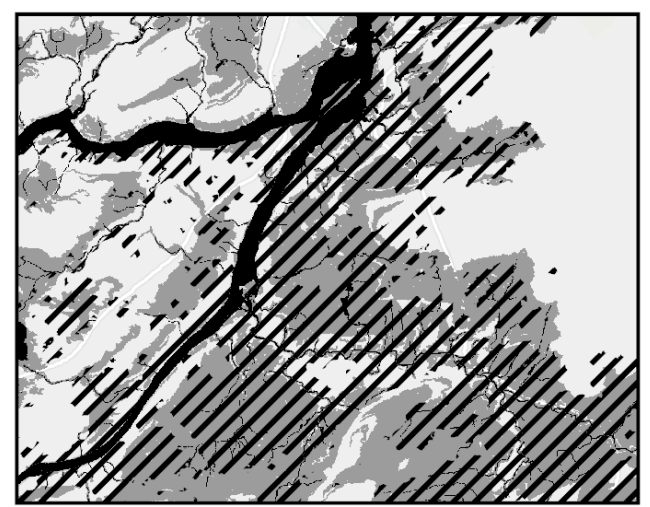

d 5 m DEM

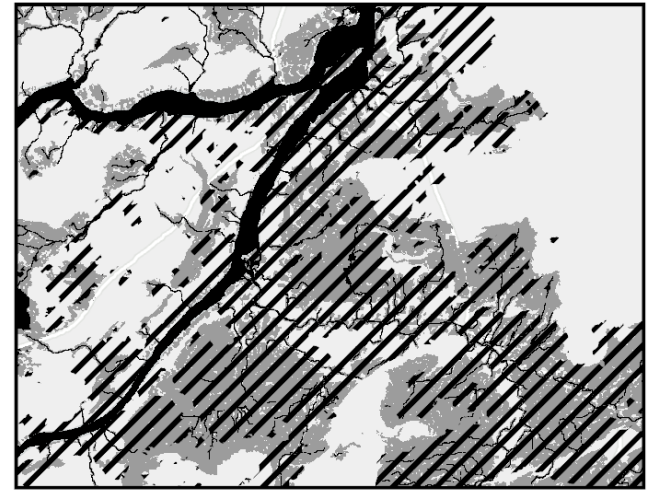

b 15 m DEM

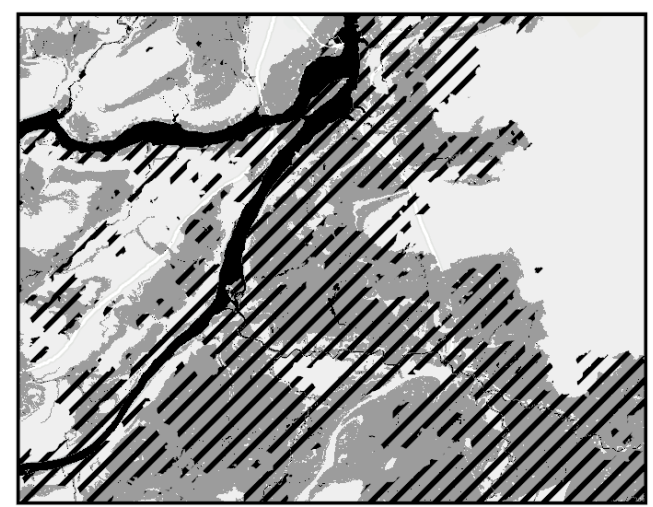

e $3 \mathrm{~m}$ DEM

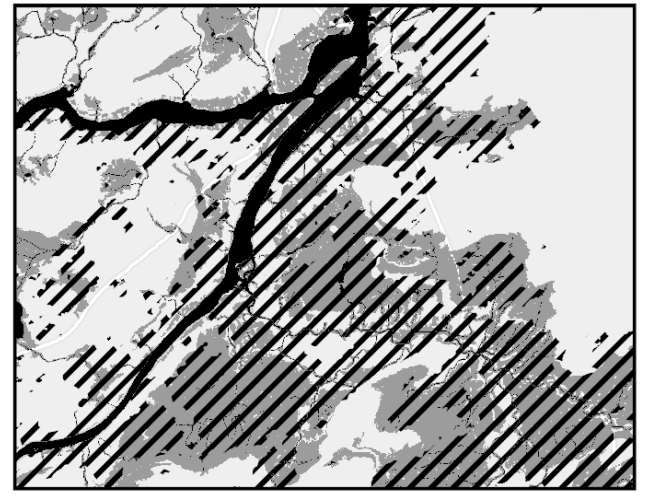

c 10 m DEM

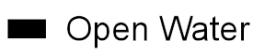

// Provincial Wetland Inventory

- ARA Wetland

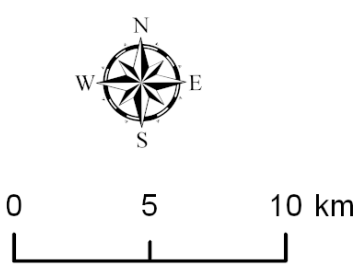

Figure 9

Portion of the result of riparian wetlands derived from different LiDAR DEMs. The extent of higherresolution riparian wetland (dark gray) (d, e) is more consistent with existing provincial wetland extent (hatched fill) as compared those of lower resolution $(a, b, c)$ 


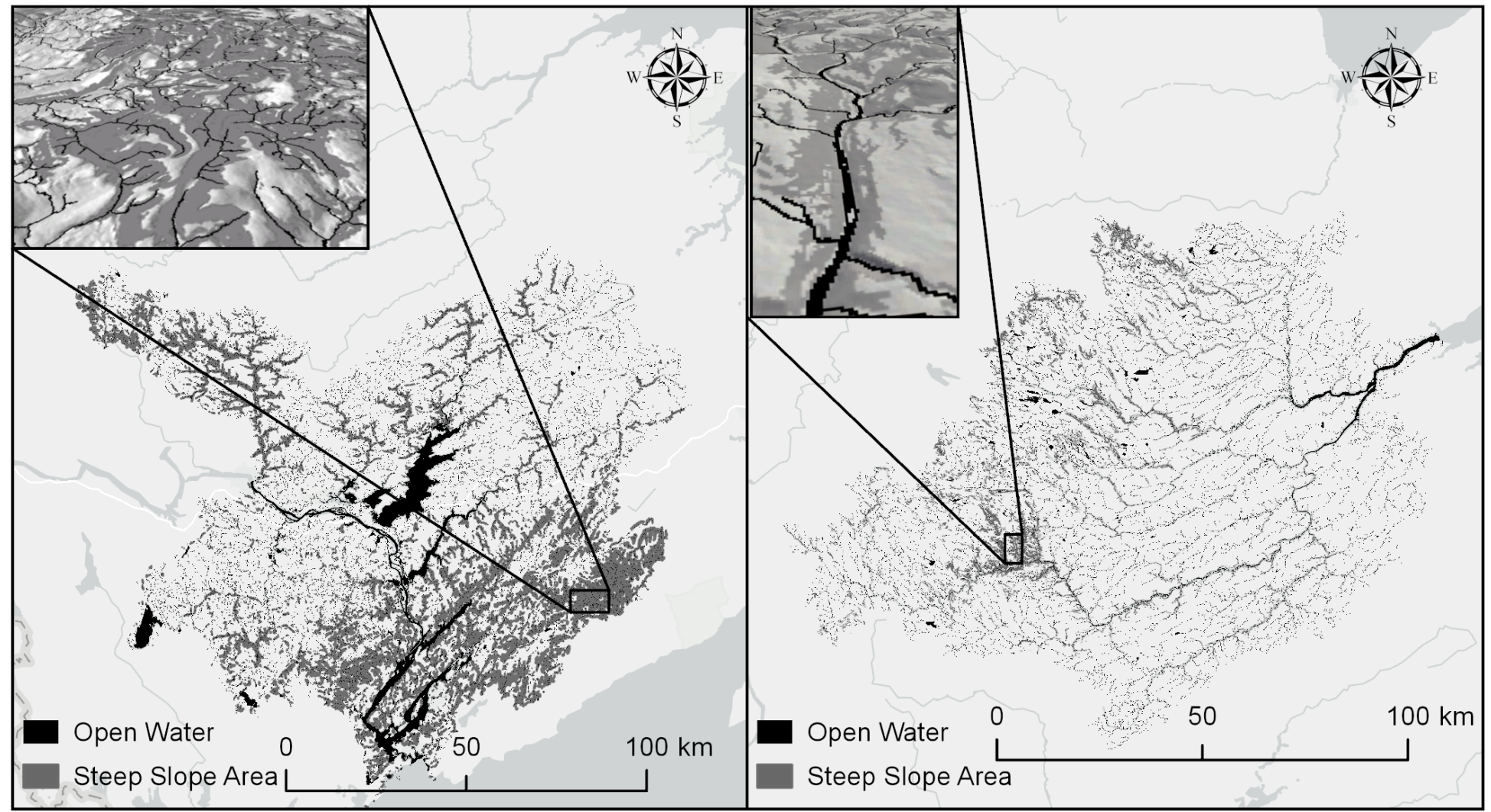

a Lower St. John River Watershed

b Miramichi River Basin Watershed

Figure 10

Steep Slope Area derived from 30-m LiDAR DEM. Inset maps show 3D versions of steep slope area 


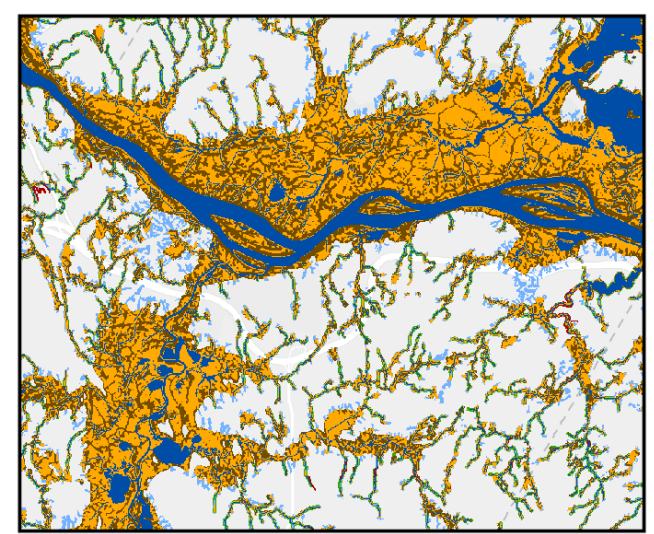

a $30 \mathrm{~m} \mathrm{DEM}$

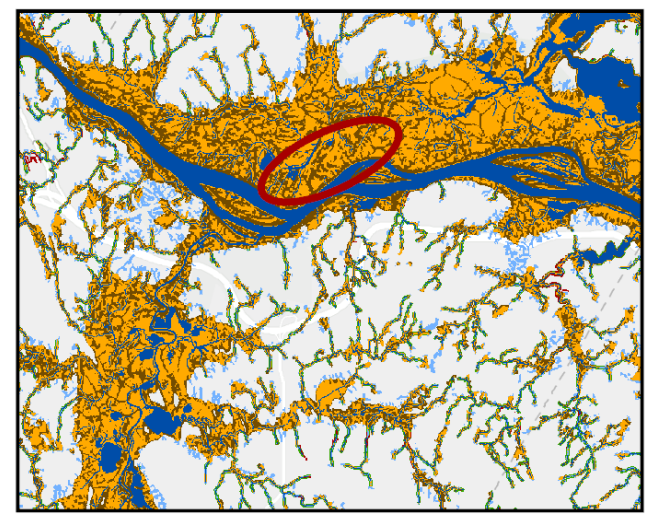

d 5 m DEM

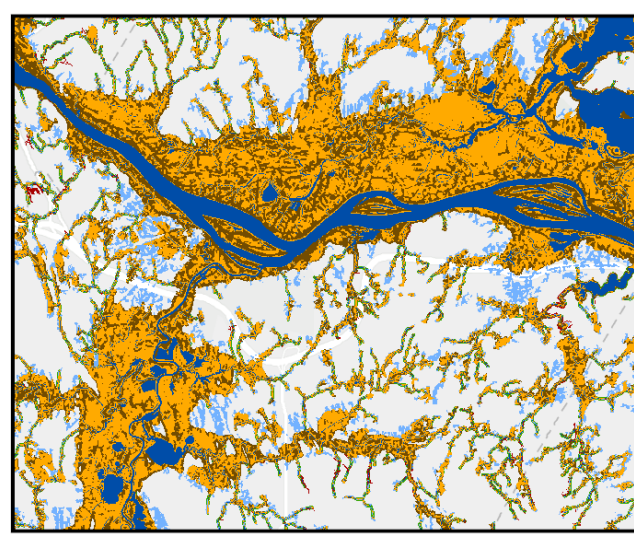

b 15 m DEM

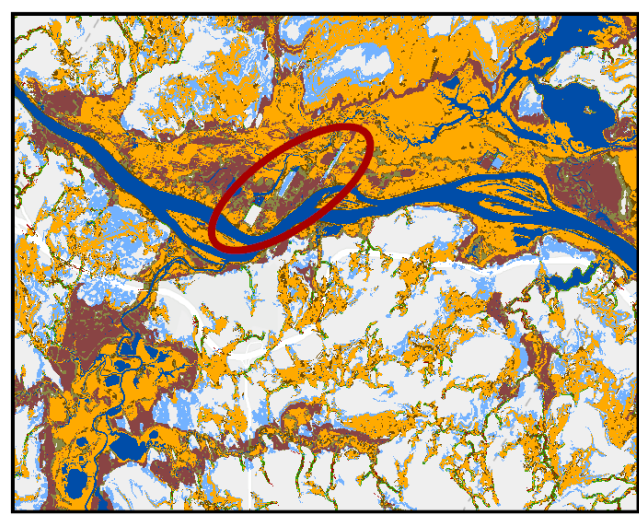

e 3 m DEM

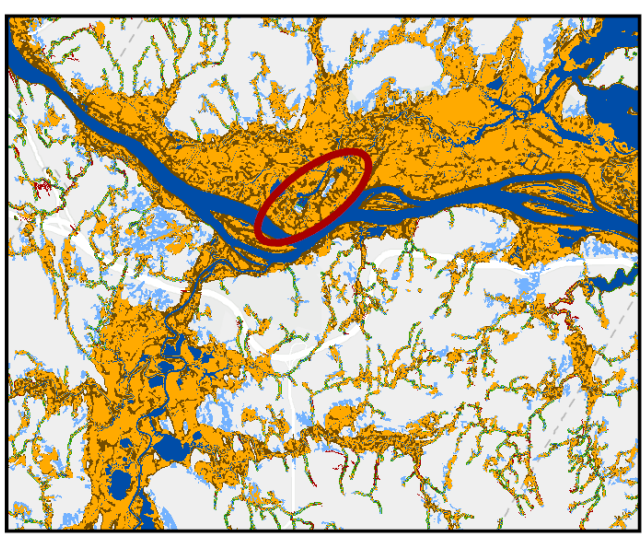

c 10 m DEM

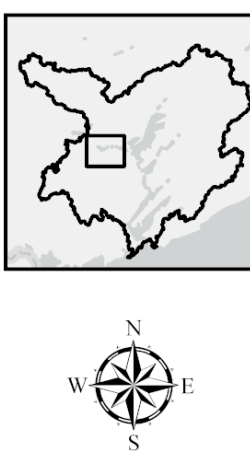

Open Water

Floodplain (non wet)

Terraces (non wet)

60-m Buffer

Steep Slope

ARA Wetland

Floodplain (wet)

Terraces (wet)

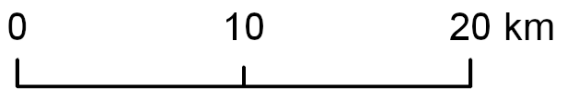

\section{Figure 11}

Portion of active river area in Lower St. John River Watershed derived from different LiDAR DEMs. Red circles (c, d, e) show examples of 'blank areas' in riparian basezones. High resolution DEM-derived ARA results $(d, e)$ show unreasonably wide creek and headwater basezones, covering large portions of active river areas 


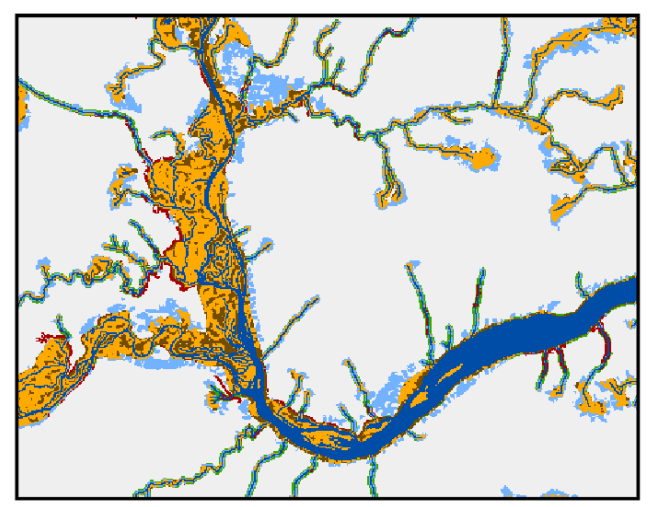

a 30 m DEM

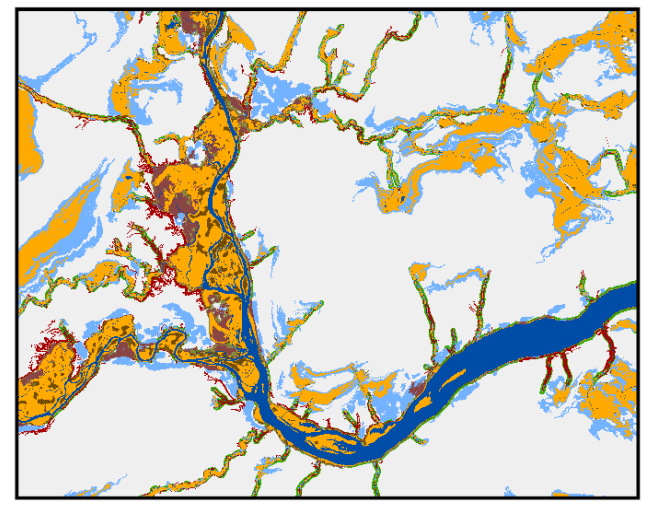

d 5 m DEM

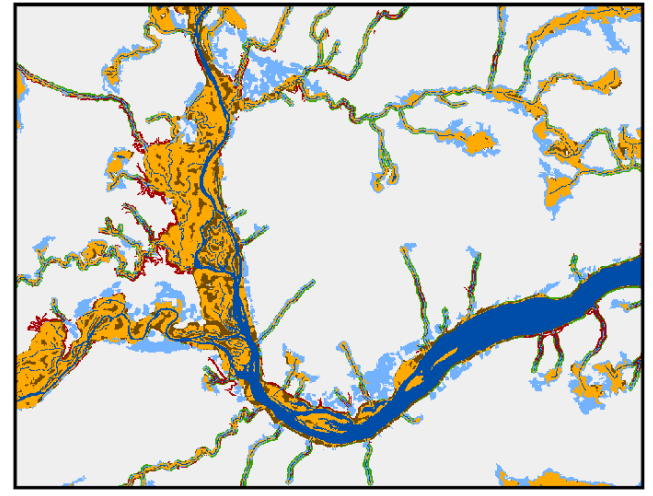

b 15 m DEM

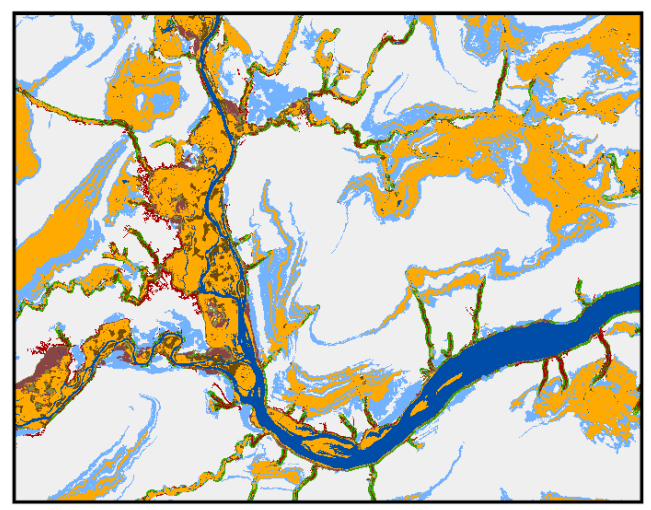

e 3 m DEM

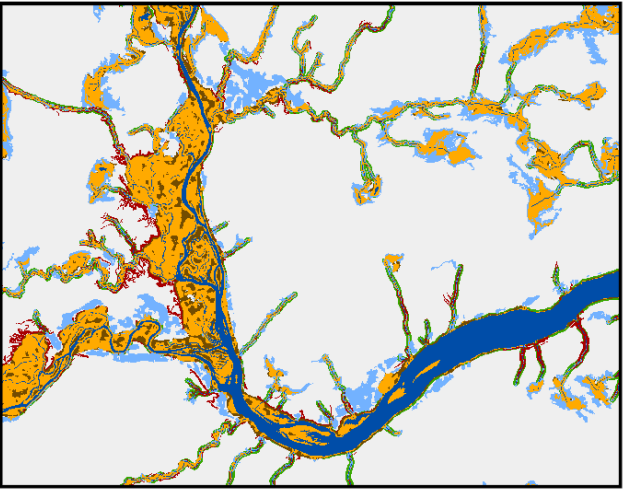

c 10 m DEM

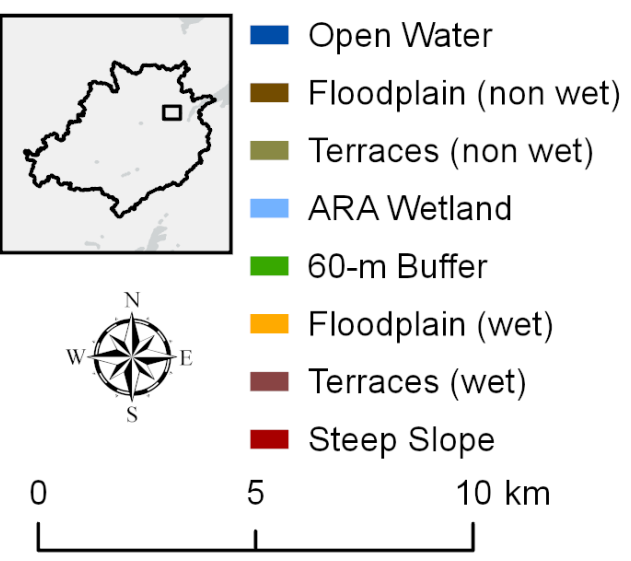

Figure 12

Portion of active river area of the Miramichi River Basin derived from different LiDAR DEMs. High resolution DEM-derived ARA results $(\mathrm{d}, \mathrm{e})$ show unreasonably wide creek and headwater basezones, covering large portions of active river areas 


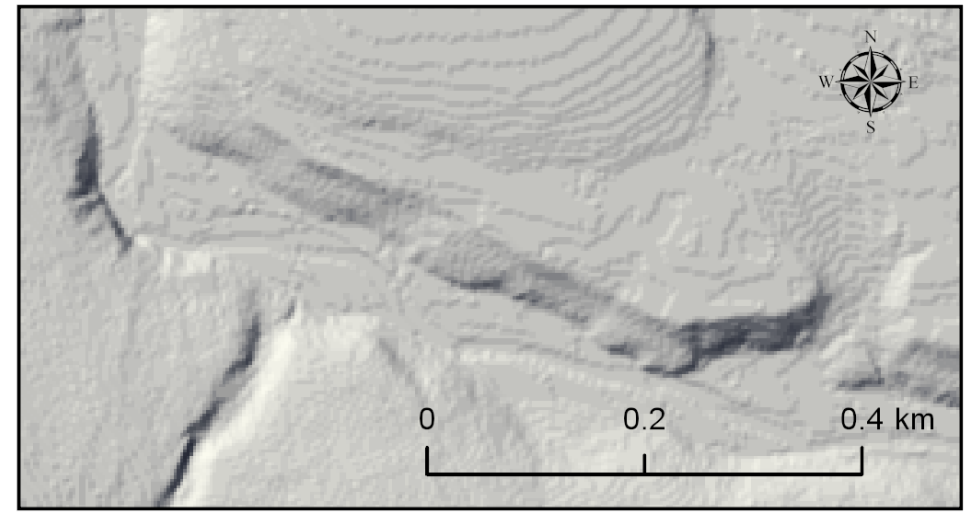

a 3-m DEM (Hillshade)

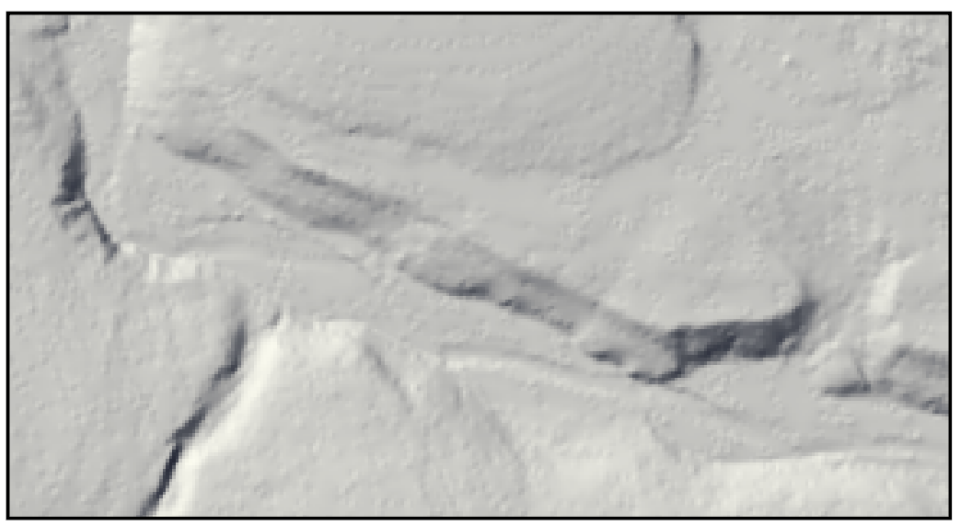

c 3-m smoothed DEM (Hillshade)

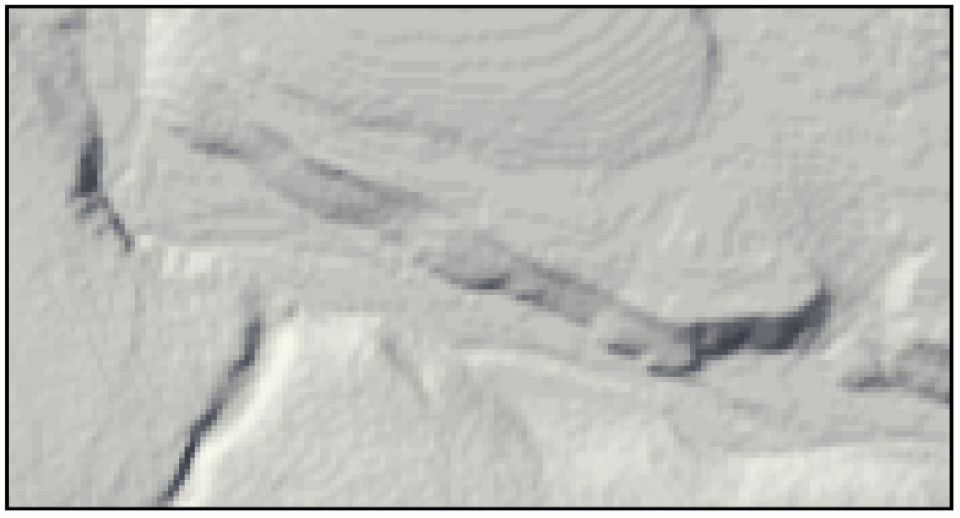

b 5-m DEM (Hillshade)

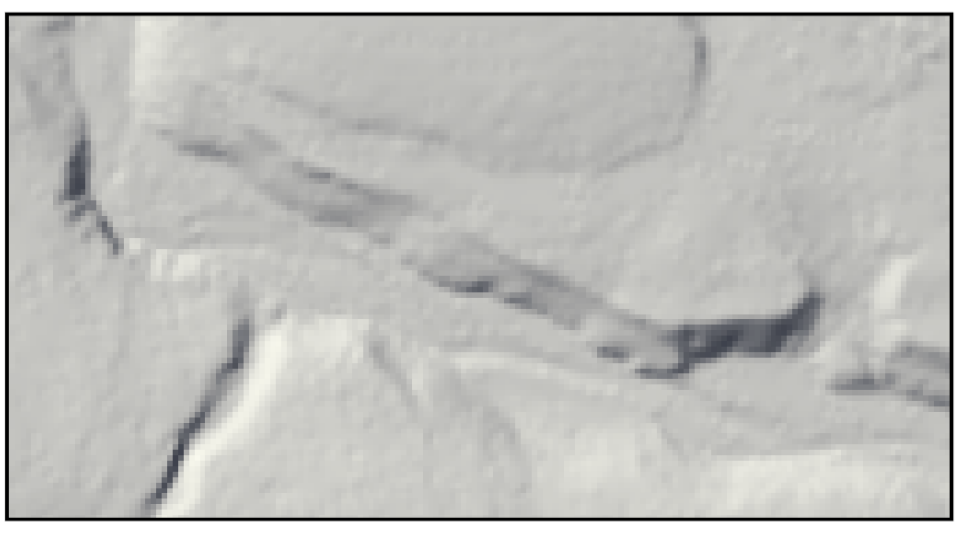

d 5-m smoothed DEM (Hillshade)

Figure 13

Comparison of raw high-resolution LiDAR DEM-derived shade relief images ( $a$ and $b$ ) and FPDEMS smoothed LiDAR DEM-derived shaded relief images (c and d) 


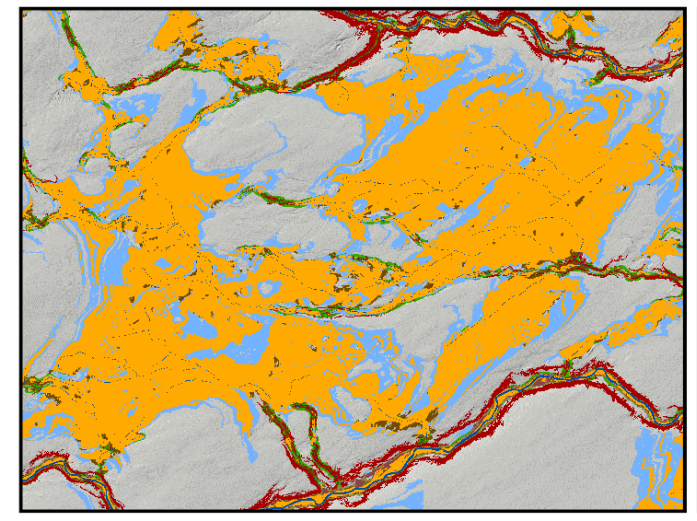

a 3-m DEM derived ARA

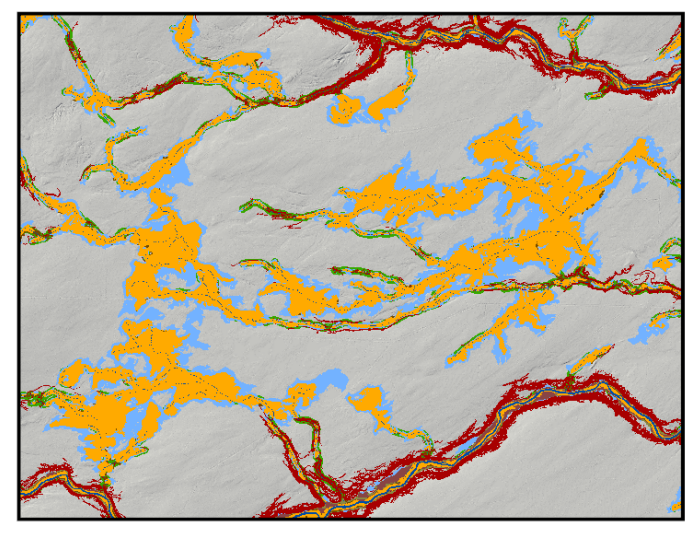

c 3-m smoothed DEM derived ARA

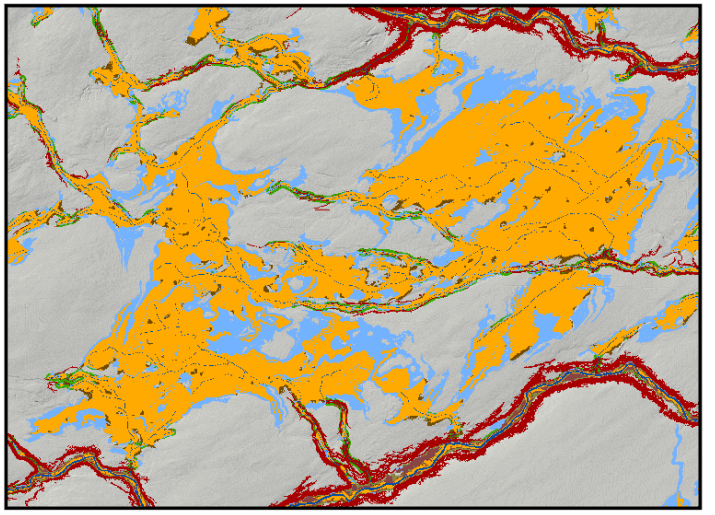

b 5-m DEM derived ARA

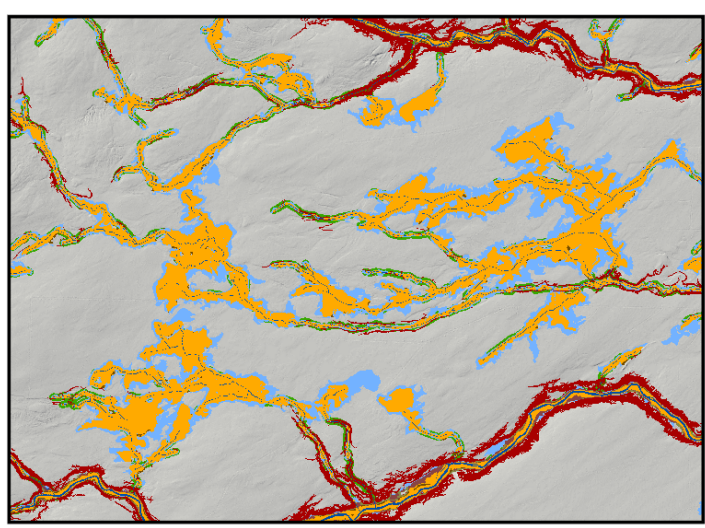

d 5-m smoothed DEM derived ARA

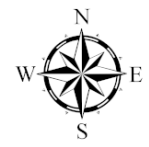

Active River Area

Open Water

Floodplain (non wet)

Terraces (non wet)

ARA Wetland

60-m Buffer

Floodplain (wet)

Terraces (wet)

Steep Slope

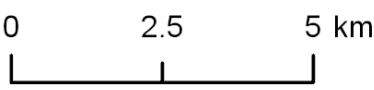

\section{Figure 14}

A comparison of raw high-resolution (3- and 5-m) DEM-derived ARA ( $a$ and $b$ ) and FPDEMS smoothed DEM-derived ARA (c and d). Images present a portion of creek and headwater area in Miramichi River Basin 

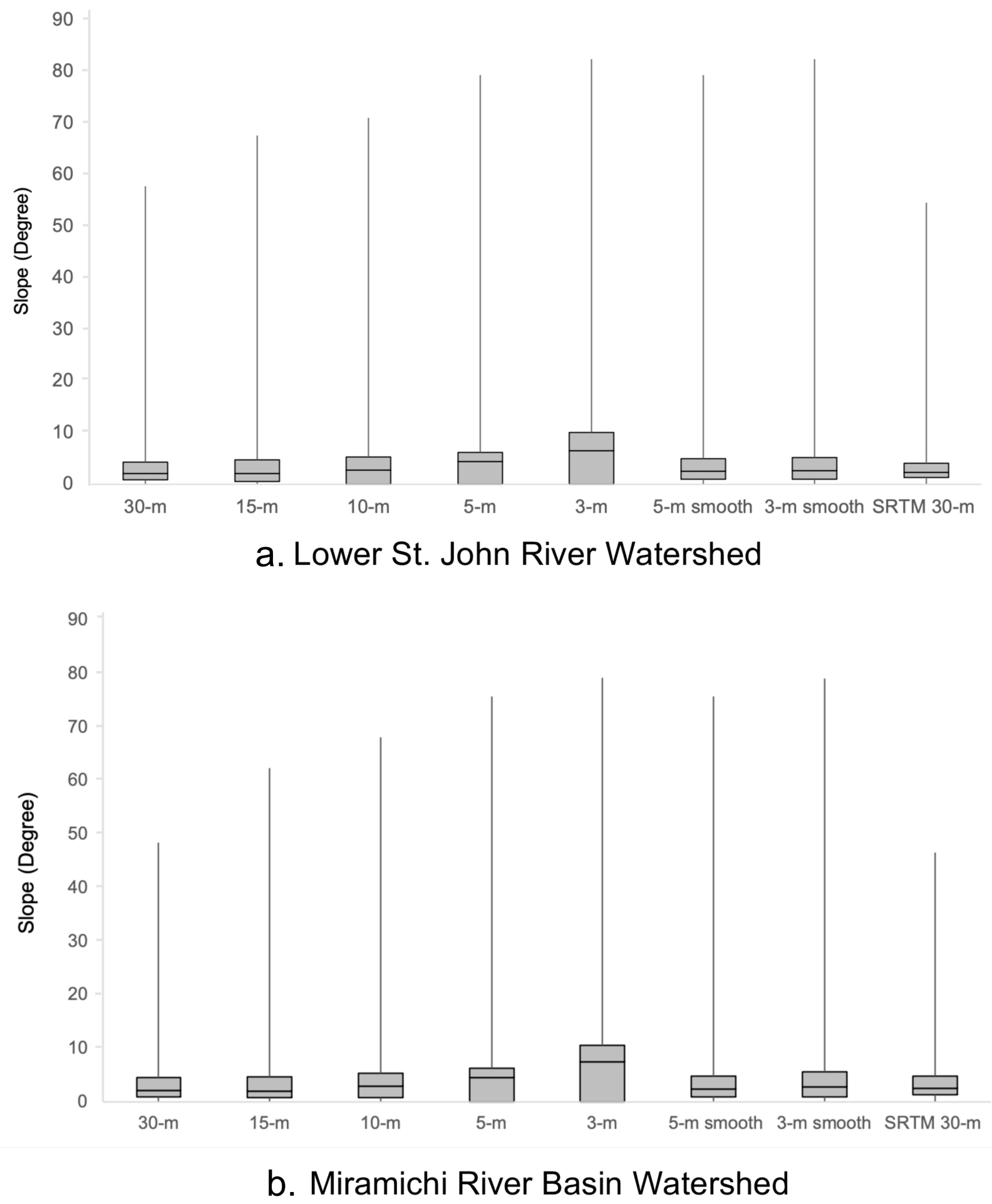

Figure 15

Value distribution of slope grids for different DEMs 


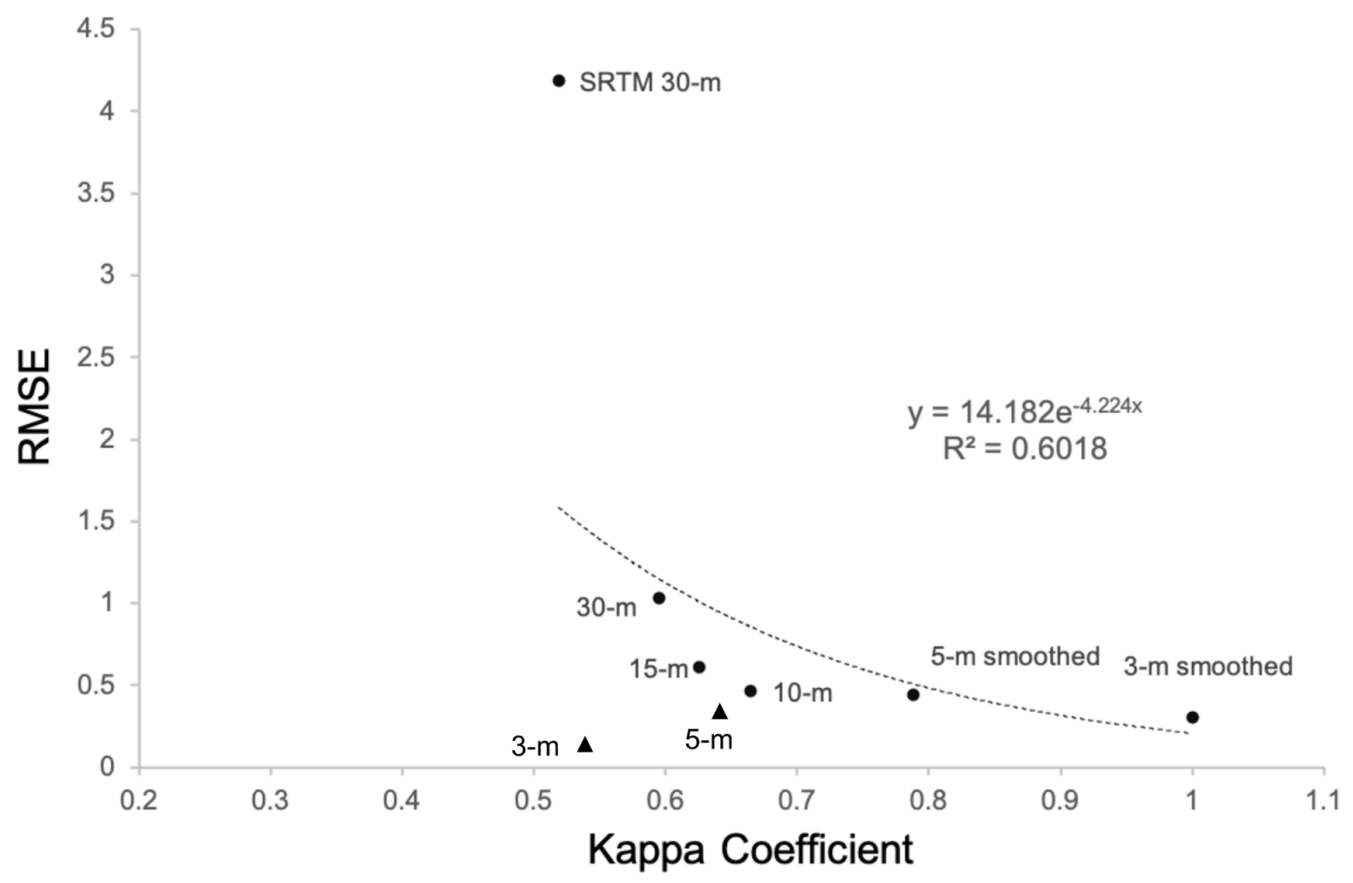

a. Lower St. John River Watershed

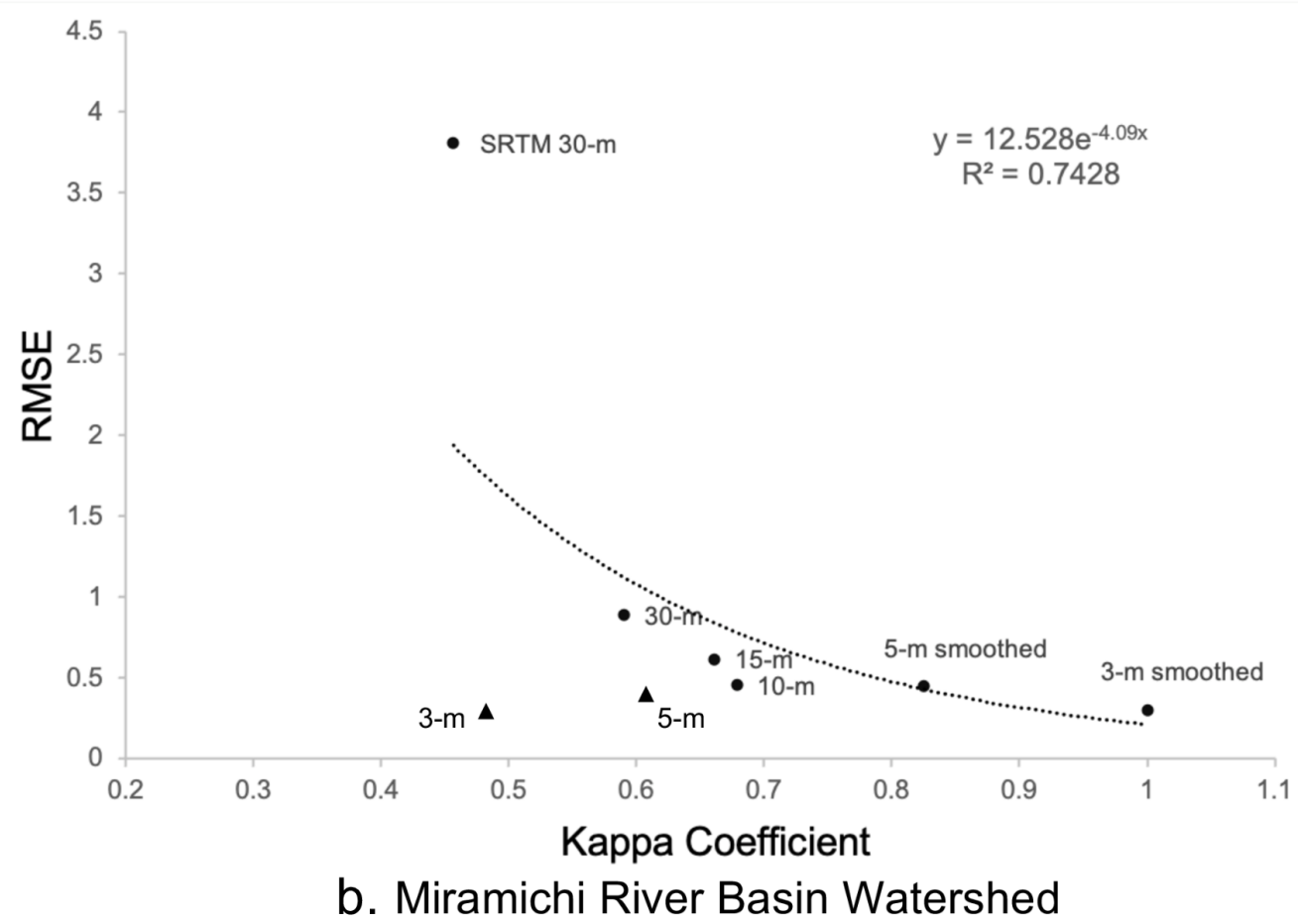

Figure 16

The relationship between DEM RMSE and ARA Kappa Coefficient. Raw 3-m and 5-m LiDAR DEM derived ARAs (triangle) were excluded from the correlation equation and R2 calculation to reduce bias 


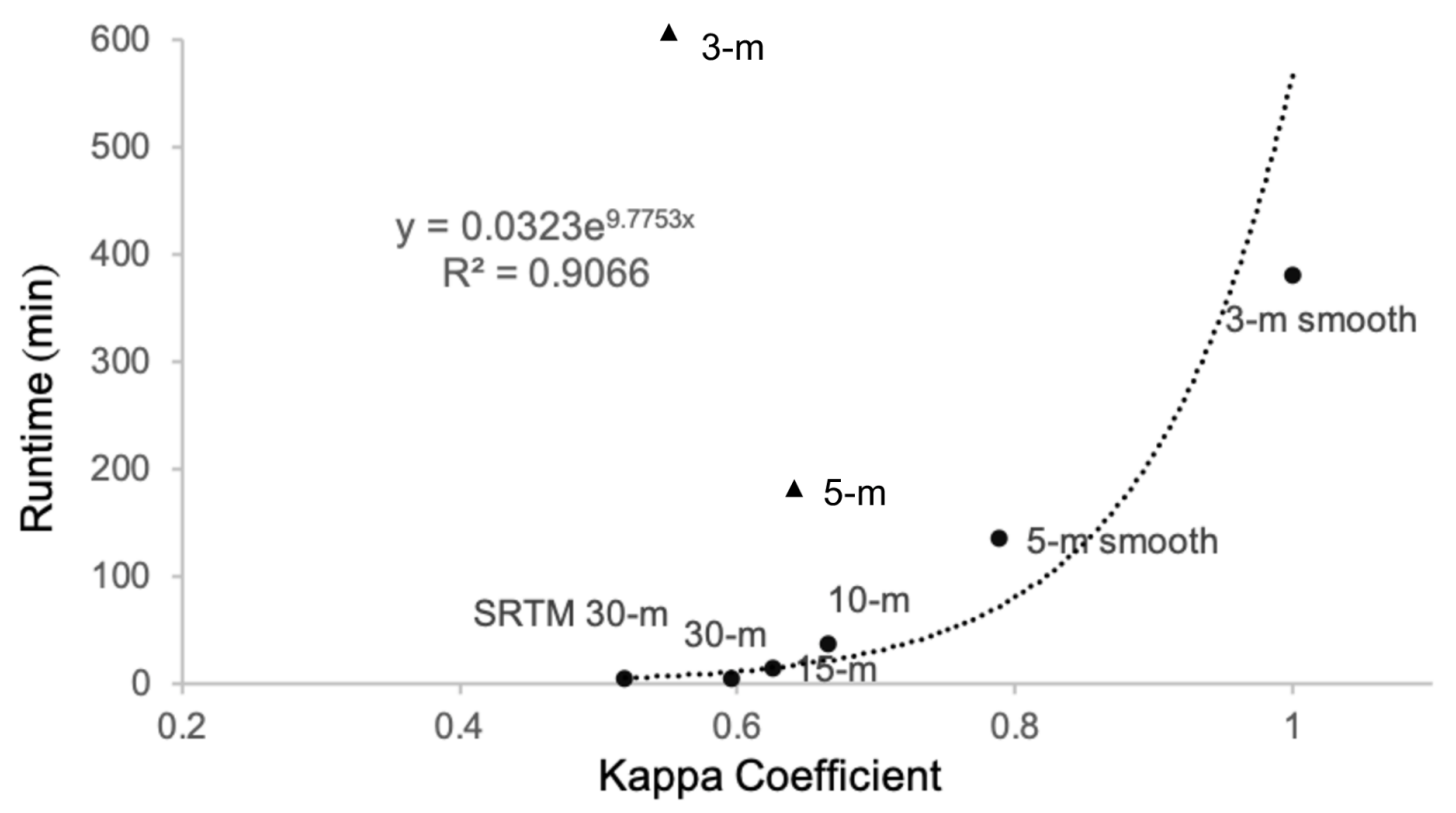

a. Lower St. John River Watershed

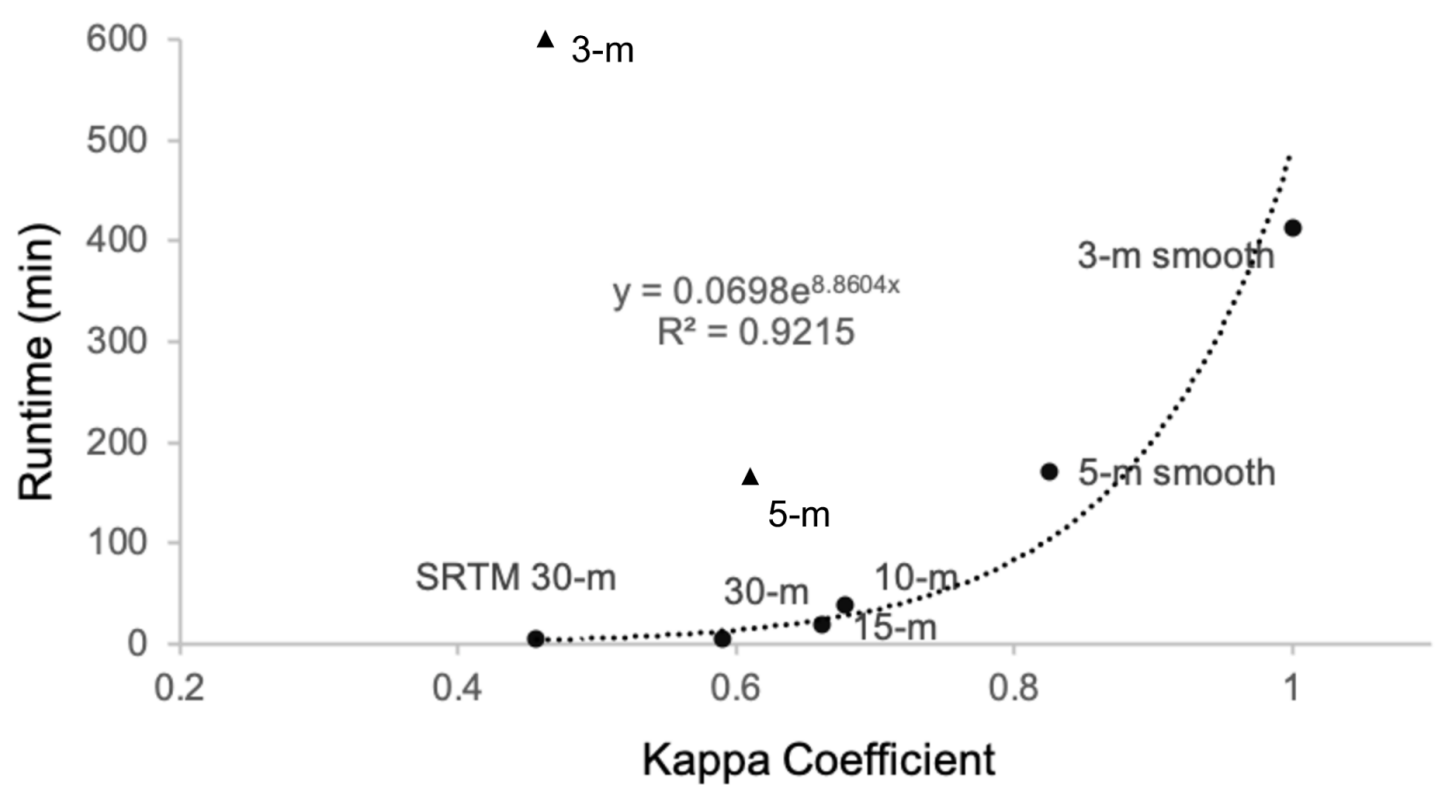

b. Miramichi River Basin Watershed

Figure 17

The relationship between runtime and Kappa Coefficient of different parallel analyses. Raw 3-m and 5-m DEM-based ARA analyses (triangle) were excluded from the correlation equation and R2 calculation, given raw 3-m and 5-m LiDAR DEM-derived ARAs contain considerable errors in creek and headwater basezones 


\section{Supplementary Files}

This is a list of supplementary files associated with this preprint. Click to download.

- formula.docx

- CoverLetterMaetal.docx

- SupplementaryInformationMaetal.docx 